\title{
The Role of Cytokines in Breast Cancer Development and Progression
}

\author{
Marcela Esquivel-Velázquez, ${ }^{1}$ Pedro Ostoa-Saloma, ${ }^{1}$ Margarita Isabel Palacios-Arreola, \\ Karen E. Nava-Castro, ${ }^{2}$ Julieta Ivonne Castro, ${ }^{2}$ and Jorge Morales-Montor ${ }^{1}$
}

Cytokines are highly inducible, secretory proteins that mediate intercellular communication in the immune system. They are grouped into several protein families that are referred to as tumor necrosis factors, interleukins, interferons, and colony-stimulating factors. In recent years, it has become clear that some of these proteins as well as their receptors are produced in the organisms under physiological and pathological conditions. The exact initiation process of breast cancer is unknown, although several hypotheses have emerged. Inflammation has been proposed as an important player in tumor initiation, promotion, angiogenesis, and metastasis, all phenomena in which cytokines are prominent players. The data here suggest that cytokines play an important role in the regulation of both induction and protection in breast cancer. This knowledge could be fundamental for the proposal of new therapeutic approaches to particularly breast cancer and other cancerrelated disorders.

\section{Introduction}

$\mathrm{T}$ HE PROCESS BY WHICH breast cancer is initiated is unknown, for which several hypotheses have emerged. Inflammation has been proposed to mediate the initiation and promotion of tumors, angiogenesis, and metastasis (Grivennikov and others 2010). Inflammatory cells are attracted by oncogenic changes, hypoxia, cytokines, and chemokines, among other factors. Inflammation in a tumor microenvironment comprises infiltrating immune cells and activated fibroblasts that secrete cytokines, chemokines, and growth factors to which the tumor responds (Coussens and Werb 2002; Grivennikov and others 2010).

Obesity can result in an inflammatory environment that can contribute to tumorigenesis. Menopause and increased age are also associated with systemic inflammation (Bruunsgaard and others 2001; Pfeilschifter and others 2002). In turn, cancer therapy can effect an inflammatory tumor microenvironment by provoking extensive tumor cell death (Baumgarten and Frasor 2012).

Several cytokines regulate the inflammatory tumor microenvironment. Interleukin (IL)-1, IL-6, IL-11, and transforming growth factor- $\beta$ (TGF- $\beta$ ) stimulate cancer cell proliferation and invasion (Nicolini and others 2006), and cytokine receptor activation and intracellular signaling by $\mathrm{NF}-\kappa \mathrm{B}$ accelerate tumor progression (Karin and Greten 2005; Hsing and others 2012).

\section{Transforming growth factor- $\beta$}

TGF- $\beta$ is the most extensively studied cytokine in breast cancer. TGF- $\beta$ belongs to the TGF- $\beta$ superfamily and is a major regulator of many processes, including proliferation, differentiation, migration, immunity, and apoptosis. TGF- $\beta$ has dual functions in tumor progression. As a tumor suppressor, it has antiproliferative effects in the early stages of tumorigenesis, but tumor cells in later stages evade this effect and progress in response to TGF- $\beta$ (Fig. 1) (Joshi and Cao 2010; Band and Laiho 2011; Inman 2011; Meulmeester and Ten Dijke 2011; $\mathrm{Zu}$ and others 2012). TGF- $\beta$, T $\beta$ RII (the receptor required for TGF- $\beta$ signaling), and phospho-Smad2 expression are associated with earlier age of onset and aggressive tumor characteristics (Figueroa and others 2010).

In the early stages of cancer, TGF- $\beta$ causes cell-cycle arrest, particularly in epithelial, endothelial, and hematopoietic cells (Massagué 2008; Heldin and others 2009; Tian and Schiemann 2010; Allington and Schiemann 2011), inhibiting cyclin-dependent kinases by downregulating c-Myc and ID1 and upregulating CDK inhibitors, including p15 and p21 (Donovan and Slingerland 2000; Feng and others 2002; Perk and others 2005; Glasgow and Mishra 2008; Massagué 2008; Juárez and Guise 2010). TGF- $\beta$ also restricts estrogen receptor $(\mathrm{ER}) \alpha$-mediated proliferation (Ewan and others 2005; Band and Laiho 2011). Many triple-negative human breast cancer cell lines, including MDA-MB-231,

\footnotetext{
${ }^{1}$ Departamento de Inmunología, Instituto de Investigaciones Biomédicas, Universidad Nacional Autónoma de México, México City, México.

${ }^{2}$ Centro de Investigación Sobre Enfermedades Infecciosas, Instituto Nacional de Salud Pública, SSA, Cuernavaca, Morelos, México.
} 

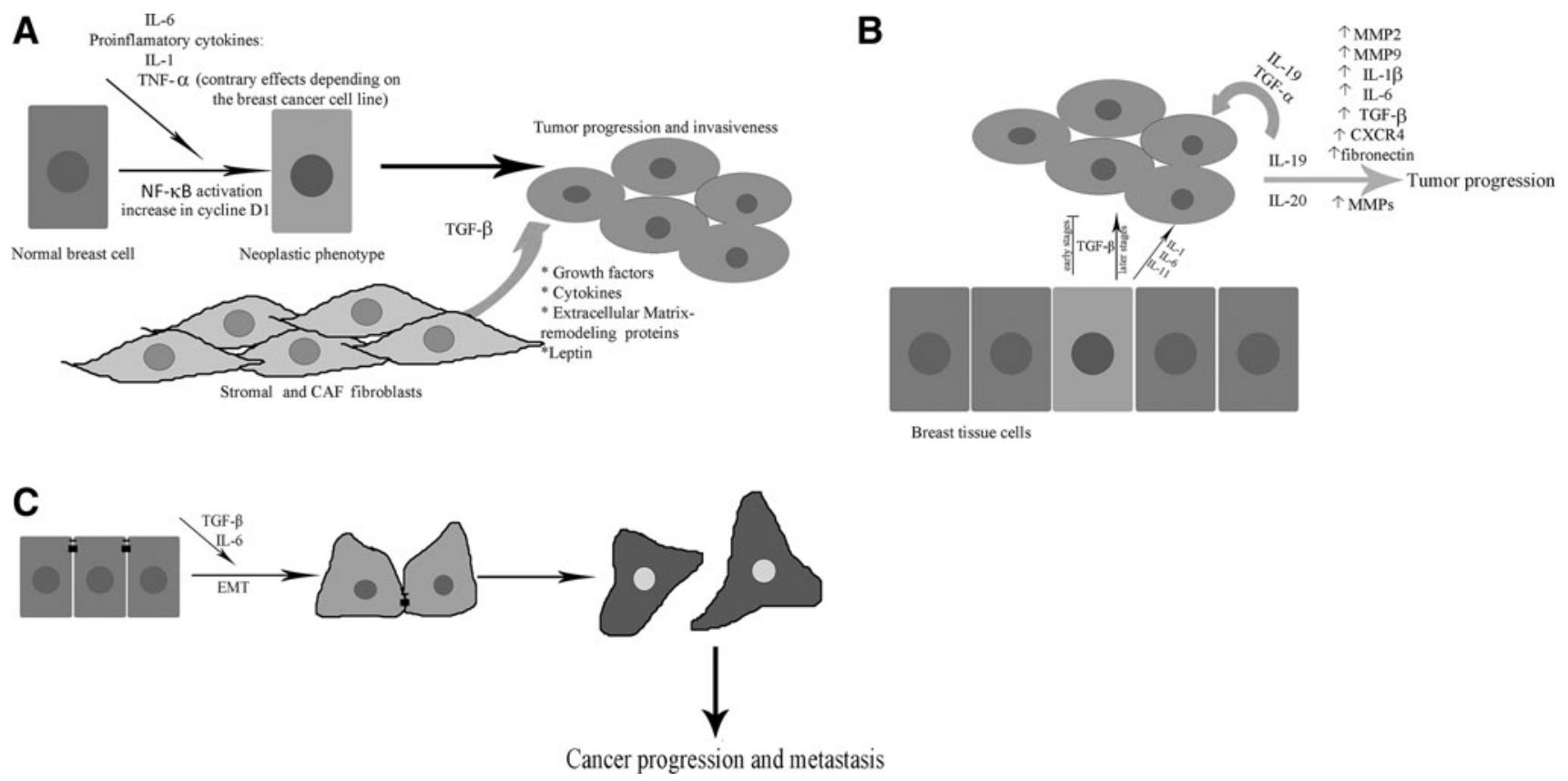

FIG. 1. Role of cytokines in the different stages of breast cancer. This figure resumes the role that different cytokines have on establishment, progression, and metastasis of breast cancer. (A) Normal cells can adopt a neoplastic phenotype by the action of IL-6, IL-1, TNF- $\alpha$, and proinflammatory cytokines, which cause NF- $\kappa$ B activation and an increase in cycline D1 in the normal breast cell, resulting in a neoplastic phenotype. (B) The proliferation of these cells, at early stages of cancer, is suppressed by TGF- $\beta$. However, at later stages, TGF- $\beta$ promotes proliferation of these cells, tumor progression, and invasiveness. (C) Stromal fibroblasts and CAFs are an important source of TGF- $\beta$. TGF- $\beta$ and IL-6 can lead to the initiation of the EMT process, which finally ends in cells that can survive not bonded to other cells and, thus, can migrate to other parts of the body and result in the spreading of the cancer.

BT20, Hs578T, HCC1937, and HCC3153, are resistant to the growth-inhibitory activity of TGF- $\beta$ (Lin and others 2012). In many cases, the antiproliferative effects of TGF- $\beta$ are attributed to altered TGF- $\beta$ signaling due to somatic mutations in components of TGF- $\beta$ signaling or selective inhibition of cytostatic responses to TGF- $\beta$. Mutations in $\mathrm{T} \beta \mathrm{R}-\mathrm{I}$ are infrequently detected in breast cancers (Imamura and others 2012).

The tumor-promoting effects of TGF- $\beta$ are complex and entail the expression and translocation of the nuclear factor of activated $\mathrm{T}$ cells into the nucleus, stimulating c-Myc expression (Singh and others 2010). TGF- $\beta$ activates Smad3/4, which, in turn, specifically binds to the HDM2 promoter and upregulates HDM2, destabilizing p53 in human breast cancer ( $\mathrm{Zu}$ and others 2012).

TGF- $\beta$ is a mediator of the epithelial-to-mesenchymal transition (EMT), which is categorized into 4 subtypes: type 1, or embryonic and developmental EMT; type 2, or tissueregeneration and fibrotic EMT; and type 3, or cancer progression and metastatic EMT (Kalluri and Weinberg 2009). Type 3 EMT has been linked to the progression and dissemination of breast cancer. TGF- $\beta$ generates polarized epithelial cells that alter their epithelial phenotype by downregulating genes which form adherent and tight junctions, remodel the cytoskeleton, and upregulate genes that are associated with cell motility and a mesenchymal phenotype (Heldin and others 2009; Wendt and others 2009; Xu and others 2009; Allington and Schiemann 2011; Zu and others 2012), promoting tumor growth and metastasis (Vincent and others 2009; Voulgari and Pintzas 2009; Wendt and others 2009; Xie and others 2012).
The mechanisms through which TGF- $\beta$ promotes the EMT are complex. For example, in Wnt signaling, the transcriptional repressor SNAIL1 affects the EMT through its interaction with Smad3 and Smad4, which downregulates CAR, occludin, claudin-3, and E-cadherin in breast epithelial cells (Vincent and others 2009). TGF- $\beta$ also upregulates TF3, a transcription factor that regulates morphology, EMT marker expression, and cancer-initiating features in breast cells (Yin and others 2010). TGF- $\beta$ communicates with Wnt, Her2, and FAK, which influence the EMT and breast cancer stem cells (BCSCs), and it promotes the formation of cancer stem cells (Taube and others 2010; Jain and Alahari 2011; $\mathrm{Zu}$ and others 2012).

\section{Interleukin-6}

Breast cancer cell lines produce IL-6, of which ER-positive cells secrete lower levels than ER-negative cells. IL-6 induces proliferation and a more aggressive phenotype in ER-positive cells (Sasser and others 2007). Fibroblasts from breast tissue also secrete IL-6, which stimulates the growth and invasiveness of MCF-7 cells (Studebaker and others 2008; Baumgarten and Frasor 2012). Further, IL-6 regulates the inducible formation and maintenance of BCSCs (Iliopoulos and others 2011). Through the IL-6 receptor/GP130 complex and STAT3 activation, IL-6 governs the self-renewal of BCSCs (Iliopoulos and others 2009, 2010; Korkaya and others 2011). Overexpression of IL-6 in MCF-7 cells induces the EMT and increases their invasiveness (Sullivan and others 2009). 
IL- 6 bridges Stat 3 and NF- $\kappa$ B-dependent inflammatory cytokines (eg, IL-1, TNF- $\alpha$ ). The initial activation of $\mathrm{NF}-\kappa \mathrm{B}$ by inflammatory signals activates a self-reinforcing regulatory circuit that comprises IL-6 and Stat 3 and converts a stable normal cellular phenotype into a stable neoplastic phenotype without any change in DNA sequence (Iliopoulos and others 2009), linking tumorigenesis to NF- $\kappa \mathrm{B}$ activation and inflammation (Ernst and Putoczki 2012).

\section{Tumor necrosis factor- $\alpha$}

Tumor necrosis factor (TNF)- $\alpha$, an inflammatory cytokine that is highly expressed in breast carcinomas (Leek and others 1998), stimulates the proliferation of T47D cells through an NF- $\kappa \mathrm{B}-d e p e n d e n t$ increase in cyclin D1 (Baumgarten and Frasor 2012). Inhibition of $\mathrm{NF}-\kappa \mathrm{B}$ and $\mathrm{TNF}-\alpha$ is protective against chemically induced breast tumorigenesis (Connelly and others 2011). Further, in vitro activation of the TNF- $\alpha / \mathrm{NF}-\kappa \mathrm{B}$ axis induces invasive and malignant behavior in breast cancer cells (Balkwill 2009). Chronic expression of TNF- $\alpha$ in breast tumors supports tumor growth (Kamel and others 2012), but the effects of $\mathrm{TNF}-\alpha$ in vitro differ between breast cancer cell lines. In contrast to its effects in T47D cells, TNF- $\alpha$ induces apoptosis (Donato and Klostergaard 2004); inhibits proliferation; and promotes migration, invasion, and resistance to chemotherapeutic drugs in MCF-7 cells (Goldberg and Schwertfeger 2010), regulating genes and enzymes that mediate estrogen metabolism, leading to higher levels of DNA adducts (Kamel and others 2012). Thus, TNF- $\alpha$ is a necrotic and tumor-promoting factor-in the tumor microenvironment, TNF- $\alpha$ enhances tumor growth and migration, whereas local administration of high doses of TNF- $\alpha$ has robust antiangiogenic and antitumoral effects (Hamed and others 2012).

\section{Interleukin-17}

IL-17, a cytokine that is secreted by CD4 and CD8 cells (6-8), is required for the development and tumor-promoting activity of myeloid-derived suppressor cells (MDSCs) in tumor-bearing mice (He and others 2010). TGF- $\beta$, IL-6, and IL-23 have been implicated in the initiation of Th17 cell differentiation in mice (Veldhoen and others 2006; Zhou and others 2007; Novitskiy and others 2011).

\section{IL-19, IL-20, TGF- $\alpha$, and IL-23}

IL-19, IL-20, TGF- $\alpha$, and IL-23 are also involved in breast tumorigenesis and tumor progression. IL-19 provides a microenvironment that is conducive to tumor progression through an autocrine effect, stimulating the proliferation and migration of cancer cells through matrix metalloproteinase (MMP)-2, MMP-9, IL-1 $\beta$, IL-6, TGF- $\beta$, CXCR4, and fibronectin (Hsing and others 2012). Studies in vitro have demonstrated that IL-19 induces the proliferation of the MCF-7 and Hs578T human breast carcinoma cell lines and of the 67NR and 4T1 murine breast cancer lines (Hsing and others 2012). IL-20 enhances the proliferation and migration of cancer cells and creates a microenvironment that fosters tumor progression by upregulating MMPs and cathepsins (Hsu and others 2012). In turn, IL-23 affects inflammation and angiogenesis in the tumor microenvironment while tempering $\mathrm{CD}^{+}{ }^{+} \mathrm{T}$-cell infiltration (Langowski and others
2006). TGF- $\alpha$ promotes tumor growth and progression through an autocrine/paracrine loop that involves EGFR (Ziober and others 1993; Humphreys and Hennighausen 2000; Booth and Smith 2007).

\section{Adipokines and Breast Cancer}

Obesity is a significant risk factor for breast cancer development. Obesity is associated with elevated levels of proinflammatory cytokines in adipose tissue and in circulation, which establishes a low-grade, chronic inflammatory state. One hallmark of obesity-associated inflammation is the recruitment of macrophages into adipose tissue. Macrophages and adipocytes produce inflammatory factors, such as adipokines and cytokines (Ouchi and others 2011), leading to the activation of NF- $\kappa \mathrm{B}$ in adipose tissue and the liver (Cai 2009; Baumgarten and Frasor 2012).

Adipokines (cytokines that are secreted by adipose tissue), such as leptin, adiponectin, IL-6, TNF- $\alpha$, and IL-1, mediate inflammatory diseases and obesity (Tilg and Moschen 2006). Glucose and fatty acids enhance the ability of adipocytes to produce factors, including IL-8, RANTES, and IGF-1, that influence cancer cell phenotypes. Stromal vascular fraction cells and differentiated adipocytes from obese individuals release more IGF-1 than those from lean individuals, suggesting that obesity favors breast cancer cell growth (D'Esposito and others 2012). Leptin synthesis and plasma levels increase with obesity (Wu and others 2009; Barone and others 2012).

In breast biopsies, IL- 1 is 1 of the 5 cytokines (with IL-2, IL-4, IL-10, and G-CSF) that are overexpressed in ductal breast carcinoma but undetected in normal breast tissue (Pantschenko and others 2003; Chavey and others 2007). The production of IL-1, even in small amounts, induces potent secondary responses, in part through its ability to elicit the secretion of other cytokines, chemokines, adhesion molecules, and receptors for cytokines from various cells (Dinarello 1996). IL-1 has been linked to the proliferation, invasion, angiogenesis, and inhibition of apoptosis in cancer cells (Apte and others 2006; Lewis and others 2006). IL-1 and IL- 8 induce breast cancer progression by enhancing metastasis and cachexia (Wolf and others 2001; Veldhoen and others 2006). IL-1 family members also modulate the activity of estrogens and their receptors-IL-1 expression is primarily observed in ER-negative breast tumors (Miller and others 2000).

IL-1-induced proliferation is mediated by the estrogensynthesizing enzymes P450 aromatase and steroid sulfatase, which generate bioactive estrogens. IL-1 enhances aromatase activity in SK-BR3 cells and steroid sulfatase activity in MCF-7 cells by $120 \%$ and $130 \%$, respectively (Honma and others 2002). IL-1 receptors are expressed in estrogen-dependent (MCF-7, ZR75-1) and estrogen-independent cell lines (MDA-MB 231) (Pantschenko and others 2003). In contrast, IL- $1 \alpha$, IL-1 $\beta$, and IL-1ra are preferentially expressed in highly malignant and invasive mammary cell lines (BT 20, BT 549, HS 578T, and MDA-MB 231) and not in the MCF-7, T47-D, ZR75-1, or SKBR-3 lines (Singer and others 2003). TNF and IL-6 upregulate aromatase in the tumor microenvironment, which might stimulate the growth of ER-positive cancers (Cleary and Grossmann 2009). TNF and IL-6 expression correlates with aromatase levels in breast cancer but not in the adjacent normal breast tissue (Irahara and others 2006). 
Leptin, a proinflammatory cytokine (Otero and others 2006), is secreted primarily by adipocytes, although breast cancer cell lines produce leptin in a process that is regulated by IL-1 (Faggioni and others 1998; O'brien and others 1999; Iguchi and others 2001). Leptin and its receptor, ObR, are expressed in normal breast epithelial cell lines and breast cancer cell lines (O'brien and others 1999; $\mathrm{Hu}$ and others 2002; Laud and others 2002). Leptin is expressed in ductal breast carcinoma but not in healthy breast tissues, and its expression correlates with the stage of invasion (CaldefieChézet and others 2005; Jardé and others 2008). Further, ObR is present in human breast carcinoma but not in normal breast tissue (Perrier and others 2009). Leptin upregulates aromatase in MCF-7 cells through a greater binding of AP-1 to promoters (Catalano and others 2003). In breast cancer, increased AP-1 levels correlate with high expression of several cytokines, including IL-1 $\beta$ (Chavey and others 2007).

ObR expression is associated with ER and tumor size (Jardé and others 2008), implicating an interaction between the leptin and estrogen systems to promote breast carcinogenesis. Several immune cells express ObRs, which might render them responsive to leptin (Martín-Romero and others 2000; Caldefie-Chezet and others 2001; Fujita and others 2002; Caldefie-Chezet and others 2003; Zhao and others 2003). In rats, elevated IL-1 $\beta$ concentrations in peripheral blood increase leptin levels and total body fat mass and stimulate the growth of mammary epithelium (Reichlin and others 2000).

Cancer cells organize their microenvironment, recruiting stromal fibroblasts in the desmoplasmic reaction; these fibroblasts and $\alpha$-smooth muscle actin-positive myofibroblasts (MFs) - collectively termed carcinoma-associated fibroblasts (CAFs) - are reprogrammed to produce growth factors, cytokines, and extracellular matrix (ECM)-remodeling proteins that act in an autocrine and paracrine manner to support tumor proliferation and invasion into surrounding tissues (Orimo and Weinberg 2006; Casey and others 2008; Kojima and others 2010; Barone and others 2012; $\mathrm{Zu}$ and others 2012) (Fig. 1).

During tumor progression, TGF- $\beta$ stimulates the progressive conversion of mammary fibroblasts into CAF MFs, promoting tumor progression (Casey and others 2008; Kojima and others 2010; Shangguan and others 2012; Zu and others 2012). Mesenchymal stem cells (MSCs) are a source of CAFs that are phenotypically similar to MFs (Ostman and
Augsten 2009). When injected with cancer cells, MSCs promote the growth and metastasis of cancers (Karnoub and others 2007; Shangguan and others 2012). MSCs are recruited to developing tumors, where they increase breast cancer cell motility, invasion, and metastatic potential by secreting chemokine (C-C motif) ligand 5 (CCL5, also known as RANTES) (Karnoub and others 2007).

In breast tumor development, leptin is a determinant of the tumor-promoting activity of CAFs in normal and K303R-mutated ER $\alpha$-expressing breast cancer cells, demonstrating that cross-talk exists between breast cancer cells and "educated" CAFs which drives tumor progression through leptin signaling (Barone and others 2012). Leptin, secreted from CAFs, binds to its receptor; activates K303R$\mathrm{ER} \alpha$; and stimulates the proliferation, migration, and invasiveness of K303R-ER $\alpha$-expressing breast cancer cells. In turn, K303R cells release factors, such as EGF, that induce CAFs to enhance leptin secretion, which might establish a positive feedback loop between cancer and stromal cells to further support breast tumor progression (Barone and others 2012). In addition to CAFs, adipose stromal cells effect invasion and metastasis by MCF-7 cells - a phenotype that is driven by IL-6 (Walter and others 2009; Baumgarten and Frasor 2012).

Adiponectin, another adipokine, might also be involved in breast cancer development. Adiponectin has antiproliferative effects on human breast cancer cells through the initiation of apoptosis and inhibition of the cell cycle (Kang and others 2005; Dieudonne and others 2006; Perrier and others 2009) (Fig. 2).

Observational evidence suggests that the risk for breast cancer decreases with intentional weight loss. Cancer incidence rates have declined in patients who have undergone bariatric surgery, whereas surgery is associated with an $83 \%$ lower risk of incident breast cancer. The ratios of percentage weight loss to percentage change in estradiol and SHBG suggest that a $10 \%$ loss in body weight affects a reduction in free estradiol levels by at least one-third. Further, a $10 \%$ loss in weight is expected to produce decreases in inflammatory markers by one-third. TNF- $\alpha$ and IL- 6 levels also decrease with intentional weight loss, albeit to a lesser extent (Byers and Sedjo 2011). Thus, intentional weight loss might be an effective prophylactic method of reducing the risk of breast cancer or a secondary treatment that improves the prognosis of breast cancer patients.

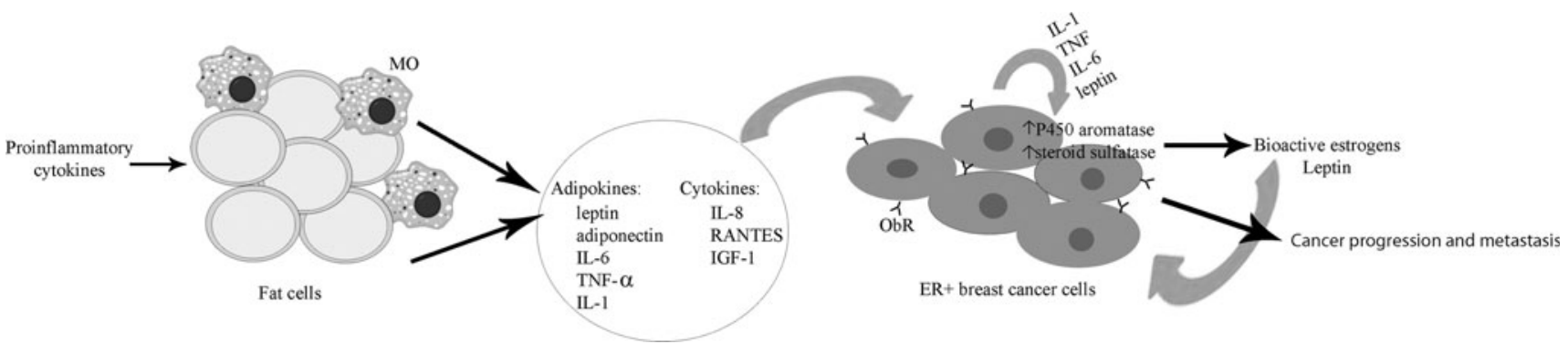

FIG. 2. Role of adipokynes and other cytokines in the progression of breast cancer. Obesity is associated with elevated levels of proinflammatory cytokines in adipose tissue and in circulation, which establishes a low-grade, chronic inflammatory state. Fat cells and macrophages (MO) associated with them produce adipokines and cytokines to which breast cancer cells respond by increasing the expression of P450 aromatase and steroid sulfatase, which, in turn, generate bioactive estrogens; and by producing several cytokines that act in an autocrine fashion. These responses lead to cancer progression and metastasis. 


\section{Cytokines and Angiogenesis}

Many cytokines participate in angiogenesis, which is essential for tumor growth and progression. TGF- $\beta$ enhances tumor vascularity by regulating the expression of cathepsin $\mathrm{G}$, vascular endothelial growth factor (VEGF), and monocyte chemotactic protein (MCP)-1 and promotes immune evasion and ECM degradation (Wilson and others 2010; Zu and others 2012). Breast cancer tumor cells overexpress bcl2 and sFas to ensure their outgrowth and survival, but this coincides with the activation of regulatory mechanisms, such as increased IL-8, TNF- $\alpha$, LPO, and NO, which attempt to halt tumor cell growth by inducing apoptosis. Ultimately, an imbalance in these mechanisms results in tumor progression, because IL- 8 , TNF- $\alpha$, and NO are also angiogenic stimulators (Hamed and others 2012; Kamel and others 2012).

Breast cancer tissues express high concentrations of IL-8 compared with normal tissue (Snoussi and others 2006), which correlates with angiogenesis (Zuccari and others 2012). IL-8 that is secreted by tumor cells enhances endothelial cell proliferation, survival, and MMP production (Hamed and others 2012). In contrast, IL-24, a member of the IL-10 family, suppresses tumor vascularization (Xie and others 2008; Hsu and others 2012).

Chronic inflammation can also lead to angiogenesis, because tumor-infiltrating lymphocytes secrete copious amounts of proinflammatory cytokines, such as IL- 6 , IL- $1 \alpha$, IL-1 $\beta$, tumor necrosis factor- $\alpha$, and oncostatin $M$, which are believed to upregulate COX-2, which, in turn, increases VEGF expression in tumor cells, promoting angiogenesis (Angelo and Kurzrock 2007). Inflammatory events can also lead to breast cancer metastasis. Further, hypoxic tumor conditions induce COX-2 expression, which activates hypoxia-inducible factor$1 \alpha($ HIF-1 $\alpha)$, a transcription factor that activates angiogenesispromoting genes, such as vegf and cox-2 (Jung and others 2003; Angelo and Kurzrock 2007) (Fig. 3).

Inflammatory breast cancer exhibits a higher expression of proangiogenic molecules, such as angiopoietin-1, VEGF, and VEGF receptors than noninflammatory breast cancer (Van der Auwera and others 2004; Angelo and Kurzrock 2007).

\section{Cytokines and Breast Cancer Metastasis}

Metastasis of breast cancer, such as tumorigenesis and tumor progression, has many mechanisms. Some cytokines in breast cancer, such as TGF- $\beta$ and IL-6, can promote tumor metastasis through the EMT (Fig. 1), a process that is characterized by reduced expression of E-cadherin and upregulation of markers, such as vimentin and $\mathrm{N}$-cadherin (Culig 2011). CAFs mediate the EMT, producing high amounts of TGF- $\beta$ (Yilmaz and Christofori 2009; Patel and others 2012).

TAMs are also linked to metastasis, secreting tumor cell migration-stimulating factors, such as CXCL12, IL-6, and TNF (Allavena and others 2008). Macrophage recruitment might be necessary for the progression of breast tumors to a metastatic state, as suggested by studies on a polyoma middle $\mathrm{T}$ oncogene (PyMT) mouse model of mammary cancer (Baumgarten and Frasor 2012). Moreover, TAMs might contribute to tumor progression, because TAMs produce estrogen and as conditioned media from TAM cultures stimulate ER-positive breast cancer cells growth (Fig. 2) (Mor and others 1998; Baumgarten and Frasor 2012).

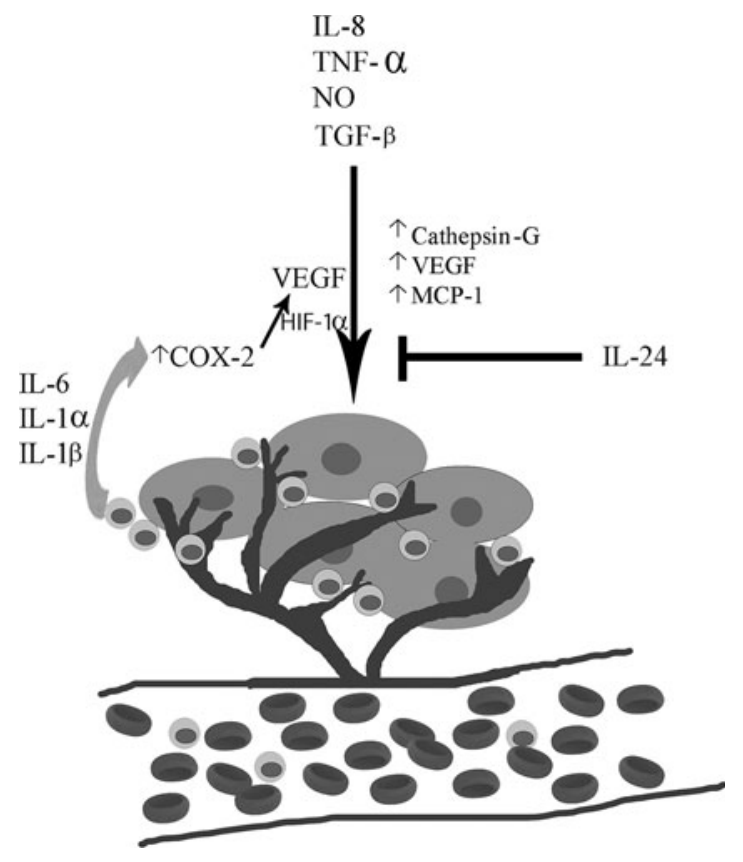

FIG. 3. Cytokines involved in angiogenesis. The inflammatory infiltrate that is usually found in breast tumors produce IL-6, IL- $1 \alpha$, and IL- $1 \beta$, which upregulate COX-2, which, in turn, increases VEGF expression in tumor cells promoting angiogenesis. IL- 8 , TNF- $\alpha$, TGF- $\beta$, and NO, produced by tumor cells, are angiogenic stimulators. TGF- $\beta$ regulates the expression of cathepsin-G, VEGF, and MCP-1, promoting extracellular matrix degradation and angiogenesis. IL-24 suppresses tumor vascularization.

Colony-stimulating factor 1 (CSF-1) might mediate the recruitment of macrophages to breast tumors (Lin and others 2001). The proto-oncogene $c$-fms encodes the only known receptor (CSF-1R) for CSF-1 (Sherr and others 1985; Dai and others 2002). The expression of CSF-1 and its receptor in neoplastic epithelial breast cancer cells correlates well with a poor prognosis and is predictive of ipsilateral recurrence (Scholl and others 1994; Maher and others 1998; Kluger and others 2004). CSF-1 promotes metastasis, stimulates angiogenesis, and participates in a paracrine loop with EGF to spur tumor cell invasion in mouse models (Lin and others 2001; Aharinejad and others 2002; Aharinejad and others 2004; Wyckoff and others 2004).

Breast cancer cell lines consistently express CSF-1 and CSF-1R, which sustains the proliferation in SKBR3 and MDAMB468 breast cancer cells through ERK1/2 activation, stimulating c-Jun and upregulating c-myc and cyclin D1. CSF-1R is not overexpressed or amplified in breast cancer cells compared with human monocytes, suggesting that the oncogenic potential of CSF-1R is attributed to its coexpression with CSF-1 (Morandi and others 2011).

TNF promotes tumor cell invasion, as evidenced in in vitro experiments, upregulating several genes that are associated with proliferation, invasion, and metastasis (Yin and others 2009; Baumgarten and Frasor 2012). IL-1 also effects the migration and metastasis of ER-positive cancer cells (Wang and others 2005; Franco-Barraza and others 2010), altering their morphology to assume more of a fibroblast-like appearance and reorganizing the actin cytoskeleton, increasing motility and MMP-9 activity (Duffy and others 2000; 
Baumgarten and Frasor 2012). Greater IL-8 expression in breast cancer patients correlates with metastasis (Simeone and others 2007).

IL-19 induces the migration of breast cancer cells, such as Hs578T and 4T1, by upregulating CXCR4, MMP-2, MMP9 , TGF- $\beta$, IL- $1 \beta$, and IL-6-factors that are involved in tumor progression and metastasis. Overexpression of IL-19 in 67NR cells, which usually have low endogenous IL-19 levels, and MCF-7 cells stimulates their proliferation and migration, enabling them to form larger tumors and metastastic micronodules in the lung on injection into mice (Hsing and others 2012). IL-20 in vitro upregulates MMP-9, MMP-12, cathepsin K, and cathepsin $\mathrm{G}$ and enhances the proliferation and migration of breast cancer cells. IL-20 is highly expressed in breast cancer bone metastases (Hsu and others 2012).

MSC-derived monocyte chemotactic protein-1 (MCP-1/ CCL2) and IL-17B promote breast cancer cell migration (Molloy and others 2009; Goldstein and others 2010; De Luca and others 2012). MSCs are a source of factors, such as VEGF and IL-6, that, in addition to promoting angiogenesis, induce breast cancer cell migration and invasion, (Beckermann and others 2008; De Luca and others 2011; De Luca and others 2012). VEGF stimulates the invasion of breast cancer cells by activating MAPK and PI3K/AKT signaling (Price and others 2001).

Hypoxia, characterized by abnormally low levels of oxygen in cells, is a feature of most solid tumors, including breast cancer. This condition orchestrates a series of effects principally regulated by the family of HIFs. HIFs, when translocated to the nucleus in response to low oxygen, induce the expression of a series of factors in cells related to proliferation and survival, metabolism, invasion and metastasis, angiogenesis, $\mathrm{pH}$ regulation, and maintenance of stem cells. Between these factors, several cytokines can be found: for example, $T G F-\alpha, I g f-2$, and Igf-Bp2 (Favaro and others, 2011). In the case of breast cancer, hypoxic conditions induce cytokine and growth factor secretion from MSCs, such as TGF- $\beta 1$, TGF- $\beta 2$, and TGF- $\beta 3$, which affects the growth, motility, and invasiveness of breast cancer cells (Hung and others 2012a, 2012b). Evenmore, TGF- $\beta$ and hypoxia (through HIF-1 $\alpha$ ) in parallel drive tumor bone metastases in breast cancer by the regulation of a common set of genes (CTGF, OPN, MMP-1, IL-6, and $I L-8$, among others) and additively increment the expression of prometastasic factors VEGF and CXCR4 (Dunn and others, 2009). TGF- $\beta$ induces the invasiveness of noncarcinogenic epithelial MCF-10A1 (M1) cells and RAS-transformed M1derived MCF-10AneoT (M2) cells in spheroid assays (Naber and others 2011). Further, levels of TGF- $\beta 1$ and TGF receptor and cell invasiveness correlate inversely with junctional adhesion molecule-A (JAM-A) expression in breast cancer cell lines (Arteaga and others 1988; Koli and Arteaga 1997; Naik and others 2008). Downregulation of JAM-A due to TGF- $\beta 1$ involves the TGF- $\beta /$ Smad and TGF$\beta /$ p54 JNK pathways, inducing breast cancer cell invasion (Wang and Lui 2012).

TGF- $\beta 1$ mediates an EMT-like process, which, in turn, can induce cancer stem cell-like properties in HMLE cells. HMLER cells, which are human primary normal mammary epithelial cells that have been immortalized using hTERT and SV40 large $\mathrm{T}$ antigen and $\mathrm{H}$-Ras to render them tumorigenic (Elenbaas and others 2001; Mani and others
2008), potentially lead to early dissemination of breast cancer cells, which can sometimes survive at sites of dissemination and may outgrow after a long latency of years (Podsypanina and others 2008; Sabe 2011).

Inflammatory breast cancer has greater metastatic potential than noninflammatory breast cancer (Van der Auwera and others 2004; Angelo and Kurzrock 2007).

\section{Cytokines, Immunosuppression, and Evasion in Breast Cancer}

Breast cancer cells have mechanisms that enable them to grow and progress. As discussed, cytokines are important mediators of tumor growth and metastasis, some of which also help the tumor evade immune responses and benefit from them. For instance, TGF- $\beta$ binds to MDSCs, causing them to suppress natural killer (NK) cells. TGF- $\beta$ also influences regulatory $\mathrm{T}$-cell activity (Yoshimura and others 2010) through a neuropilin-1 (Nrp1)-mediated mechanism and supports breast cancer growth (Glinka and Prud'homme 2008; $\mathrm{Zu}$ and others 2012).

IL-10 has not only been implicated in the immunosuppression in breast cancer, but it is also involved in the antitumor response. IL-10 is a potent anti-inflammatory cytokine that inhibits gene expression, cytokine synthesis by $\mathrm{T}$ cells and macrophages, and their antigen presentation. IL-10 suppresses the production of IL- $1 \alpha$, IL- $1 \beta$, TNF- $\alpha$, IL-6, IL-8, IL12, IL-18, granulocyte-macrophage colony-stimulating factor (GM-CSF), MIP-1 $\alpha$, RANTES, leukemia-inhibiting factor, and itself (Moore and others 1993; Hamidullah and others 2011).

TAMs are a significant source of IL-10 in the tumor microenvironment. TAMs have an immunosuppressive phenotype, characterized by the release of IL-10, likely in response to $\mathrm{S} 1 \mathrm{P}$ from dying cancer cells through a complex signaling network that requires S1PR/src-dependent trafficking of TRKA to the plasma membrane in primary human macrophages, on which autocrine NGF induces PI3K/AKT signaling (Weigert and others 2007).

Tumor-associated plasmocytoid dendritic cells (TApDCs) affect immune tolerance through tumor-associated regulatory T-cell expansion and differentiation of IL-10-secreting $\mathrm{T}$ cells. The selective suppression of IFN- $\alpha$ production gives TApDC the unique ability to sustain FoxP3 ${ }^{+}$Treg expansion, contributing to immune tolerance by the tumor and poor clinical outcomes (Sisirak and others 2012).

Moreover, tumor cell lines which are cultured in vitro express IL-10, suggesting that IL-10 establishes an immunesuppressive tumor microenvironment. However, overexpression of IL-10 in tumor cells that have been transplanted in mice causes tumors to be rejected, implicating $\mathrm{CD}^{+} \mathrm{T}$ cells, NK cells, or IL-10 (Zheng and others 1996; Moore and others 2001; Mumm and others 2011).

\section{Cytokines as Prognostic Factors in Breast Cancer}

In addition to their effects on tumor progression, the levels of several cytokines have been correlated with tumor stage, survival, and malignancy, rendering them potential prognostic factors.

High levels of TGF- $\beta$ have been linked to worse survival in breast cancer patients, and plasma TGF- $\beta$ levels might be 
predictive of local and distant metastasis (Grau and others 2008; Bierie and others 2009; Ivanović and others 2009; Yu and others 2010; $\mathrm{Zu}$ and others 2012). Loss of Wnt5a, which is directly regulated by TGF- $\beta$, is associated with early relapse of invasive breast cancer, increased metastasis, and poor survival in breast cancer patients (Serra and others 2011). Higher circulating levels of TGF- $\beta 2$ correlate with nonpremenopausal status, infiltrating ductal carcinoma, higher histological grade, presence of vascular permeation and lymphocytic infiltration, and longer relapse-free survival, making them likely to be used as a marker of favorable prognosis (Dave and others 2011).

Reduced and increased expression of TGF- $\beta 3$ in breast tumor biopsies is associated with a poor and a good prognosis, respectively (van de Vijver and others 2002). Similarly, lower TGF- $\beta 3$ mRNA levels correlate with higher tumor grade (van de Vijver and others 2002; Miller and others 2005; Ivshina and others 2006; Sotiriou and others 2006; Desmedt and others 2007). Conversely, higher circulating levels of TGF- $\beta 3$ and TGF- $\beta 3$-receptor complexes are linked to the presence of lymph node metastases (Laverty and others 2009). Further, TGF- $\beta 3$ is central to the parity-induced protection against breast cancer, which occurs in women who give birth before the age of 24 years. Parity induces chronic upregulation of TGF- $\beta 3$ (D'Cruz and others 2002; Laverty and others 2009).

IL-1 family members have prognostic value in breast cancer. IL-1 is expressed particularly in ER-negative breast tumors. Levels of IL-1 in the serum and tumor correlate with invasiveness and a poor prognosis (Goldberg and Schwertfeger 2010). Elevated levels of IL-1 $\beta$ are associated with invasiveness and aggressiveness of breast cancer and higher tumor grade (Jin and others 1997; Chavey and others 2007). High IL-1 receptor antagonist (IL-1ra) levels and low levels of IL-1 at the tumor site are linked to a good prognosis in breast cancer-in the healthy population, individuals with low serum IL-1ra concentrations have higher levels of adiponectin (Rafiq and others 2007); these correlate with increased expression of ERs (Pantschenko and others 2003). Low serum levels of adiponectin are a risk factor for the development of breast cancer in postmenopausal women (Miyoshi and others 2003; Hou and others 2007; Perrier and others 2009).

Moreover, serum IL-6 levels are significantly higher in breast cancer patients than in healthy women, and increased IL-6 levels correlate with poorer survival and diminished response to endocrine therapy in patients with metastatic breast cancer (Zhang and Adachi 1999; Knüpfer and Preiss 2007; Culig 2011; Baumgarten and Frasor 2012; Liu and others 2012a). Plasma from benign breast tumor patients have significantly elevated levels of IL-6 compared with normal controls (Nariţa and others 2011). Patients with high IL-6 concentrations have worse responses to chemotherapy and hormone therapy (Zhang and Adachi 1999). IL-6 levels are lower in breast cancer patients who respond better to therapy (Zhang and Adachi 1999; Guo and others 2012). Nevertheless, IL-6 levels have been reported as positive and negative predictors in breast cancer (Knüpfer and Preiss 2007).

IL-19 expression in breast cancer tissue is associated with a higher mitotic rate, advanced tumor stage, metastasis, and worse disease-specific and metastasis-free survival (Hsing and others 2012), implicating it in progression of the tumor.
In breast cancer, IL-8 is associated with lymph nodepositive status, higher stage, and lack of hormone receptors (Zuccari and others 2012). Serum IL-8 has been linked to accelerated clinical progression, greater tumor load, and the presence of lymph node and liver metastases (Benoy and others 2004; Culig 2011). Patients with HER-2/neu + tumors have increased serum IL-8 levels versus those with HER-2/ neu- tumors (Vazquez-Martin and others 2007). In contrast, patients with local recurrence or metastases have lower IL-8 levels (Zuccari and others 2012). Plasma IL-8 levels are higher in stage III and IV breast cancer patients compared with stage I and II (Hamed and others 2012).

Circulating TNF levels correlate with higher tumor stage and lymph node metastasis (Sheen-Chen and others 1997). TNF levels are greater in invasive breast cancer tissue than in benign tissue (Miles and others 1994; Baumgarten and Frasor 2012). IL-13 levels show a similar correlation of TNF levels and clinicopathological characteristics in breast cancer patients (Srabovic and others 2011). Higher TNF- $\alpha$ expressing populations correlate with increasing tumor grade and node involvement (Kamel and others 2012). Similarly, TNF- $\alpha$ plasma levels are elevated in stage II, II, and IV breast cancer patients versus those with stage I and healthy controls (Hamed and others 2012).

IL-10 concentration is frequently higher in the serum of breast cancer patients compared with normal subjects. Elevated IL-10 might inhibit tumor growth by suppressing IL-6 production, based on the inverse correlation between IL-6 and IL-10 levels in cancer patients (Kozłowski and others 2003). IL-10 is overexpressed in ER-negative versus ERpositive breast tumors (Chavey and others 2007). A correlation between IL-10 level and clinical stage has also been reported (Merendino and others 1996) - metastatic disease is associated with higher IL-10 levels than nonmetastatic disease, which might contribute to impaired immunosurveillance, favoring tumor development.

IL-20 is associated with advanced tumor stage, greater tumor metastasis, poor clinical outcome, higher mitotic rate, and worse survival (Hsu and others 2012). Elevated IL-23 levels in breast cancer patients correlate with shorter overall survival (Gangemi and others 2012).

In contrast, higher circulating soluble IL-2R levels appear to be a favorable prognostic indicator (Nicolini and others 2006; Gangemi and others 2012) (Table 1).

\section{Cytokines and Quality of Life in Breast Cancer Patients}

Quality of life is a significant issue in breast cancer patients and survival. Patients experience pain, sleep disturbances, and fatigue, even after treatment has ended. More than $54 \%$ of patients develop moderate to severe pain during the treatment trajectory (van den Beuken-van Everdingen and others 2007; Starkweather and others 2013).

Increasing evidence suggests that modulation of immune activation through a greater secretion of proinflammatory cytokines accelerates the development of distressing symptoms in women with breast cancer (Lyon and others 2008; Reyes-Gibby and others 2008; Starkweather and others 2013).

Increased levels of IL-1 and IL-6 are associated with pain and sleep disturbances in breast cancer survivors (ColladoHidalgo and others 2006; Starkweather and others 2013). A significant rise in plasma IL-1ra is also linked to post-treatment 


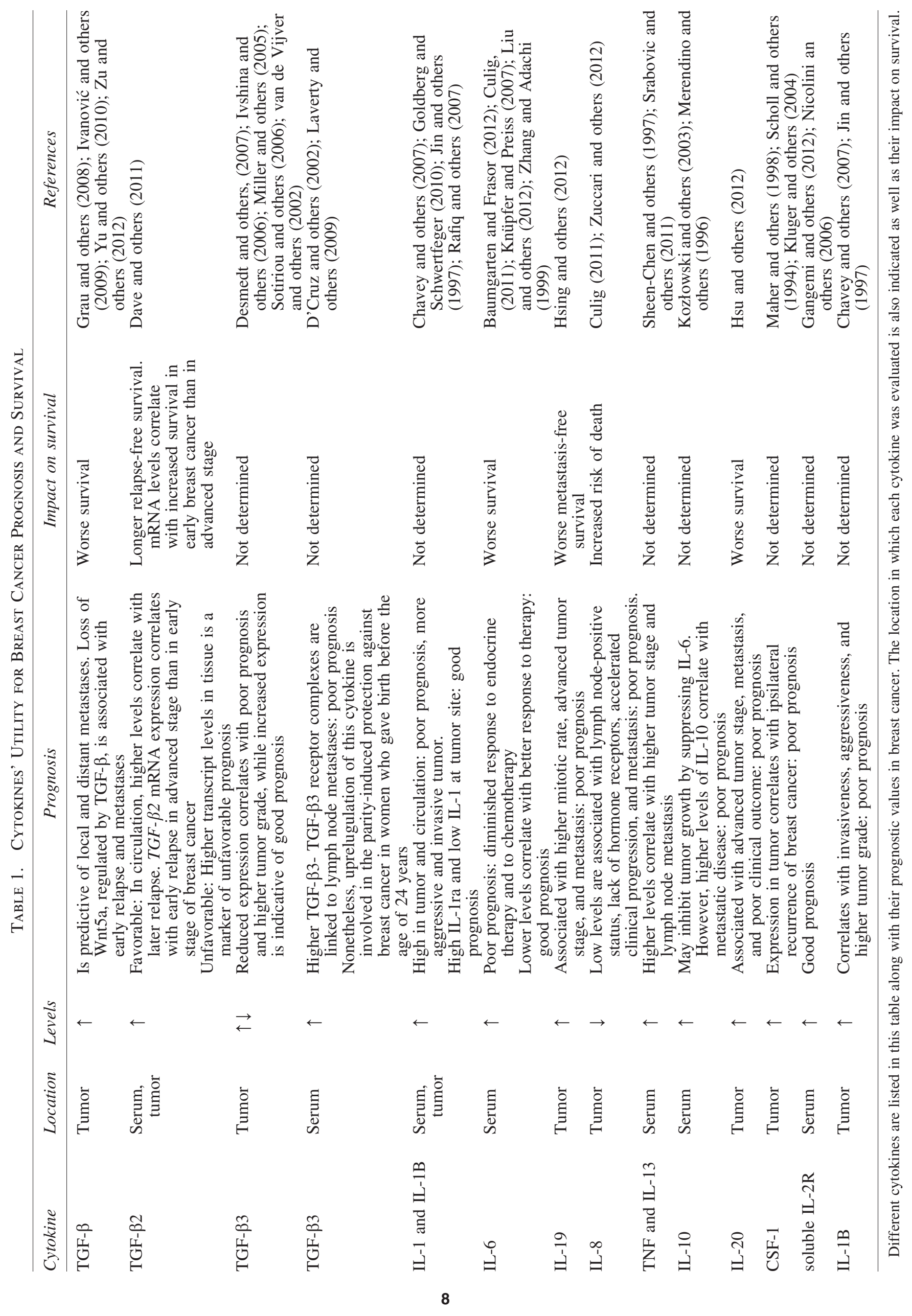


fatigue in breast cancer survivors (Bower and others 2002; Perrier and others 2009). Similarly, IL-17, IL-13, and CRP levels are higher in women who experience pain, greater pain interference, depression, and sleep disturbances (Starkweather and others 2013). Further, VEGF and soluble intercellular adhesion molecule-1 (sICAM-1) levels are associated with fatigue in patients who are undergoing chemotherapy (Mills and others 2005), as are elevated levels of IL-1RA, soluble tumor necrosis factor receptor type II (sTNF-RII), neopterin, and soluble IL-6 receptor, which have been correlated with fatigue in breast cancer patient survivors at 5 years after diagnosis (Karayiannakis and others 2001; Bower and others 2002; Collado-Hidalgo and others 2006; Berger and others 2012).

CRF might be the pathway at which several systems converge, including the central nervous system, immunoregulatory pathways, and the neuromusculoskeletal and cardiopulmonary systems. The physiological and immunological systems, which control inflammatory pathways, might be involved in CRF (Harvey and others 2009). Moreover, sleep problems have been associated with CRF, depression, and poorer overall quality of life (Lis and others 2008; Schultz and others 2011; Berger and others 2012). Sleep regulatory functions can also be affected by cytokines, such as IL-1, IL-6, and TNF- $\alpha$ (Vgontzas and others 1997; Opp 2005; Raison and others 2010; Liu and others 2012b).

\section{Cytokines and Breast Cancer Treatment}

Based on their function in breast cancer development, cytokines are attractive targets for new treatments. Further, cytokines can potentiate or impair the efficacy of current breast cancer therapies. For instance, in the presence of IL1, the selective ER modulator (SERM) 4-hydroxytamoxifen (4-OHT) activates, rather than represses, the transcription of ER target genes. IL-1 displaces an inhibitory complex that contains NCoR from ER target gene promoters, inhibiting their response to 4-OHT (Zhu and others 2006). Thus, IL-1 might regulate ER activity and responsiveness to endocrine therapy (Baumgarten and Frasor 2012).

TNF- $\alpha$ promotes chemotherapeutic resistance in MCF-7 cells through upregulation of ABCG2, an ATP-binding cassette transporter that effluxes chemotherapeutic drugs from cancer cells (Krishnamurthy and Schuetz 2006; Mosaffa and others 2009; Pradhan and others 2010; Baumgarten and Frasor 2012; Malekshah and others 2012). TGF- $\beta$ signaling also affects the resistance of breast cancer cells to DNA-damaging chemotherapeutic agents ( $\mathrm{Yu}$ and others 2010; $\mathrm{Zu}$ and others 2012), and it might also induce immunosuppression and lead to resistance and relapse in breast cancer (Joffroy and others 2010; Zu and others 2012).

IL-6 and IL-8 are also related to multidrug resistance in breast cancer cells. Only breast cancer cells that are sensitive to drugs do not express IL-6, whereas multidrug-resistant breast cancer cells produce high levels of IL-6 (Guo and others 2012). Neutralization of IL-6 and IL-8 with antibodies significantly enhances the sensitivity of resistant MCF-7 cells to drugs, and their overexpression increases the resistance of MCF-7/Sensitive cells to chemotherapeutic drugs. Further, IL-6 and IL-8 can be induced by chemotherapeutic drugs (Shi and others 2012), which can lead to multidrug-resistant cells.
IL-6 can mediate trastuzumab (anti-HER2/neu mAb) resistance in breast cancer cells by activating an IL-6-dependent inflammatory feedback loop that causes the expansion of CSCs. IL-6 might induce the CSC phenotype in non-CSC cells. Long-term trastuzumab treatment generates highly enriched CSCs that have an EMT phenotype, secreting over 100 times more IL6 than parental cells. Blocking this IL-6 loop with an antibody against IL-6 receptor interrupts this inflammatory feedback mechanism and decreases the CSC population, resulting in lower tumor growth and metastasis (Korkaya and others 2012).

As therapeutic agents, GM-CSF and granulocyte colonystimulating factor (G-CSF) have been evaluated with regard to their value in preventing or reducing the incidence of febrile neutropenia (FN) due to high-dose intensive cytotoxic chemotherapy. FN often requires hospitalization and intravenous antibiotics. Peter and others (2013) performed a meta-analysis of several clinical trials and demonstrated that that CSF is beneficial in the prevention of NF. However, CSF can cause adverse events, such as bone pain and injection-site reactions. No conclusions could be drawn from this metaanalysis, as the studies had a few patients, varying definitions, and unclear measurements of trial outcomes.

IFNs, IL-2, and IL-12, cytokines that induce hormone sensitivity and stimulate cellular immunity, have also been used to treat advanced breast cancer (Swain 1991; Fehniger and others 2002; Hsing and others 2012). Although treatment with IL- 2 or IL- 6 alone, IL- 2 combined with IFN- $\alpha$, G-CSF or trastuzumab, and IL-12 and trastuzumab is well tolerated (Nicolini and others 2006), they had no clear antitumor effect or have improvement beyond each individual treatment. Clinical outcome was also not improved (Nicolini and Carpi 2008). Treatment with IFNs (IFN- $\alpha$, IFN- $\beta$, and IFN- $\gamma$ ), alone or in combination, had no immunological effects or significantly improved clinical outcomes compared with conventional treatment (Nicolini and Carpi 2008).

TGF- $\beta$ is a notable target, based on its tumor-supportive function in late-stage tumors. Several approaches for the blocking of TGF- $\beta$ signaling have been developed, including antibodies. The 1D11 antibody, which blocks all 3 isoforms of TGF- $\beta$, inhibits $4 \mathrm{~T} 1$ growth and metastasis. In contrast, blockade of TGF- $\beta$ in MDAMB-231 cells, which, unlike 4T1 cells, express low levels of TGF- $\beta$, does not affect their growth (Liu and others 2012a). TGF- $\beta$ blockade normalizes the tumor vasculature, improves chemotherapy delivery into tumors, and decreases angiogenic gene expression, including VEGF and IL-8 (Liu and others 2012a). Further, TGF- $\beta$ blockade normalizes the interstitial matrix by reducing collagen density, improving the transport of nanoparticles from the perivascular space into deeper areas of the tumor, and enhancing the treatment of breast cancer patients (Liu and others 2012a).

1D11 prevents bone metastasis in animal models, significantly reducing tumor burden in the bone and osteolytic lesion areas. Tumor-bearing mice which have been treated with 1D11 double their bone volume, suggesting that antiTGF- $\beta$ can be used to treat bone loss in breast cancer (Biswas and others 2011). Moreover, inhibition of TGF- $\beta$ signaling in human bone marrow MSCs blocks their differentiation into CAFs, induced by the tumor microenvironment, and the consequent protumor effects, improving the safety of MSC-based therapies in cancer patients (Shangguan and others 2012). 
Normalization of abnormal vessels in mammary tumors can also be achieved by blocking vascular endothelial growth factor receptor-2 with DC101, an anti-VEGF-receptor-2, improving the delivery of smaller nanoparticles (diameter, $12 \mathrm{~nm}$ ) while hindering that of larger nanoparticles (diameter, $125 \mathrm{~nm}$ ) (Chauhan and others 2012), which can be valuable in directing specific drugs to the tumor.

TGF- $\beta$ signaling can be blocked with other approaches, such as translational inhibition by antisense oligonucleotides, small-molecule inhibitors, and peptide aptamers to Samd proteins (Kelly and Morris 2010; Zu and others 2012). GC1008 and 2G7 are 2 other high-affinity monoclonal antibodies to TGF- $\beta$ that can neutralize all 3 isoforms, but they are associated with certain drawbacks, such as side effects, including generalized inflammation, autoimmune reactions, and tumorigenic risk (Kim and others 2001; Cheng and others 2008; $\mathrm{Zu}$ and others 2012).

The mAb7E anti-IL-20 also reduces tumor growth, suppresses bone colonization, mitigates osteolysis, and improves bone density in mice that have been injected with breast cancer cells (Hsu and others 2012).

\section{Concluding Remarks}

New data on breast cancer immunology from the past several years suggest that many long-established and widely accepted paradigms be revised. We have reviewed data that have led to novel models of the biology and function of breast cancer cells. The cytokines that we have discussed are regulated by molecules which were originally believed to be exclusive to the endocrine system: sex steroids. These findings engendered a new concept of bidirectional communication between the endocrine and immune systems under normal circumstances, not necessarily during disease. Finally, the development of drugs that specifically target cytokines, such as the IL-6/sIL-6R pathway, will be valuable in the treatment of breast cancer, in which immune inflammation has a protagonic function.

\section{Acknowledgments}

Financial support: Grant \# IN-214011 from Programa de Apoyo a Proyectos de Investigación e Innovación Tecnológica (PAPIIT) from Dirección General de Asuntos del Personal Académico (DGAPA), Universidad Nacional Autónoma de México (U.N.A.M.), and Grant 176803, from Programa de Fondos Sectoriales CB-SEP, Consejo Nacional de Ciencia y Tecnología (CONACyT), both to Jorge Morales Montor. Karen Nava-Castro has a postdoctoral fellowship from CONACyT. Margarita Isabel Palacios-Arreola is a PhD student at Programa de Doctorado en Ciencias Biomédicas.

\section{Author Disclosure Statement}

No competing financial interests exist.

\section{References}

Aharinejad S, Abraham D, Paulus P, Abri H, Hofmann M, Grossschmidt K, Hofbauer R. 2002. Colony-stimulating factor-1 antisense treatment suppresses growth of human tumor xenografts in mice. Cancer Res 62(18):5317-5324.

Aharinejad S, Paulus P, Sioud M, Hofmann M, Zins K, Schäfer R, Abraham D. 2004. Colony-stimulating factor-1 blockade by antisense oligonucleotides and small interfering RNAs suppresses growth of human mammary tumor xenografts in mice. Cancer Res 64(15):5378-5384.

Allavena P, Sica A, Solinas G, Porta C, Mantovani A. 2008. The inflammatory micro-environment in tumor progression: the role of tumor-associated macrophages. Crit Rev Oncol Hematol 66(1):1-9.

Allington TM, Schiemann WP. 2011. The Cain and Abl of epithelial-mesenchymal transition and transforming growth factor- $\beta$ in mammary epithelial cells. Cells Tissues Organs 193(1-2):98-113.

Angelo LS, Kurzrock R. 2007. Vascular endothelial growth factor and its relationship to inflammatory mediators. Clin Cancer Res 13(10):2825-2830.

Apte RN, Krelin Y, Song X, Dotan S, Recih E, Elkabets M, Voronov E. 2006. Effects of micro-environment- and malignant cell-derived interleukin-1 in carcinogenesis, tumour invasiveness and tumour-host interactions. Eur $\mathrm{J}$ Cancer (Oxford, England: 1990) 42(6):751-759.

Arteaga CL, Tandon AK, Von Hoff DD, Osborne CK. 1988. Transforming growth factor beta: potential autocrine growth inhibitor of estrogen receptor-negative human breast cancer cells. Cancer Res 48(14):3898-3904.

Balkwill F. 2009. Tumour necrosis factor and cancer. Nat Rev Cancer 9(5):361-371.

Band AM, Laiho M. 2011. Crosstalk of TGF- $\beta$ and estrogen receptor signaling in breast cancer. J Mammary Gland Biol Neoplasia 16(2):109-115.

Barone I, Catalano S, Gelsomino L, Marsico S, Giordano C, Panza S, Andò S. 2012. Leptin mediates tumor-stromal interactions that promote the invasive growth of breast cancer cells. Cancer Res 72(6):1416-1427.

Baumgarten SC, Frasor J. 2012. Minireview: inflammation: an instigator of more aggressive estrogen receptor (ER) positive breast cancers. Mol Endocrinol 26(3):360-371.

Beckermann BM, Kallifatidis G, Groth A, Frommhold D, Apel A, Mattern J, Herr I. 2008. VEGF expression by mesenchymal stem cells contributes to angiogenesis in pancreatic carcinoma. Br J Cancer 99(4):622-631.

Benoy IH, Salgado R, Van Dam P, Geboers K, Van Marck E, Scharpé S, Dirix LY. 2004. Increased serum interleukin-8 in patients with early and metastatic breast cancer correlates with early dissemination and survival. Clin Cancer Res 10(21):7157-7162.

Berger AM, Gerber LH, Mayer DK. 2012. Cancer-related fatigue: implications for breast cancer survivors. Cancer $118(8$ Suppl):2261-2269.

Bierie B, Chung CH, Parker JS, Stover DG, Cheng N, Chytil A, Moses HL. 2009. Abrogation of TGF-beta signaling enhances chemokine production and correlates with prognosis in human breast cancer. J Clin Invest 119(6):1571-1582.

Biswas S, Nyman JS, Alvarez J, Chakrabarti A, Ayres A, Sterling J, Mundy GR. 2011. Anti-transforming growth factor $\beta$ antibody treatment rescues bone loss and prevents breast cancer metastasis to bone. PloS One 6(11):e27090.

Booth BW, Smith GH. 2007. Roles of transforming growth factor-alpha in mammary development and disease. Growth Factors 25(4):227-235.

Bower JE, Ganz PA, Aziz N, Fahey JL. 2002. Fatigue and proinflammatory cytokine activity in breast cancer survivors. Psychosom Med 64(4):604-611.

Bruunsgaard H, Pedersen M, Pedersen BK. 2001. Aging and proinflammatory cytokines. Curr Opin Hematol 8(3):131-136.

Byers T, Sedjo RL. 2011. Does intentional weight loss reduce cancer risk? Diabetes Obes Metab 13(12):1063-1072. 
Cai D. 2009. NFkappaB-mediated metabolic inflammation in peripheral tissues versus central nervous system. Cell Cycle 8(16):2542-2548.

Caldefie-Chézet F, Damez M, de Latour M, Konska G, Mishellani F, Fusillier C, Vasson M-P. 2005. Leptin: a proliferative factor for breast cancer? Study on human ductal carcinoma. Biochem Biophys Res Commun 334(3):737-741.

Caldefie-Chezet F, Poulin A, Tridon A, Sion B, Vasson MP. 2001. Leptin: a potential regulator of polymorphonuclear neutrophil bactericidal action? J Leukoc Biol 69(3):414-418.

Caldefie-Chezet F, Poulin A, Vasson MP. 2003. Leptin regulates functional capacities of polymorphonuclear neutrophils. Free Radic Res 37(8):809-814.

Casey TM, Eneman J, Crocker A, White J, Tessitore J, Stanley M, Plaut K. 2008. Cancer associated fibroblasts stimulated by transforming growth factor beta1 (TGF-beta 1) increase invasion rate of tumor cells: a population study. Breast Cancer Res Treat 110(1):39-49.

Catalano S, Marsico S, Giordano C, Mauro L, Rizza P, Panno ML, Andò S. 2003. Leptin enhances, via AP-1, expression of aromatase in the MCF-7 cell line. J Biol Chem 278(31): 28668-28676.

Chauhan VP, Stylianopoulos T, Martin JD, Popović Z, Chen O, Kamoun WS, Jain RK. 2012. Normalization of tumour blood vessels improves the delivery of nanomedicines in a sizedependent manner. Nat Nanotechnol 7(6):383-388.

Chavey C, Bibeau F, Gourgou-Bourgade S, Burlinchon S, Boissière F, Laune D, Lazennec G. 2007. Oestrogen receptor negative breast cancers exhibit high cytokine content. Breast Cancer Res 9(1):R15.

Cheng N, Chytil A, Shyr Y, Joly A, Moses HL. 2008. Transforming growth factor-beta signaling-deficient fibroblasts enhance hepatocyte growth factor signaling in mammary carcinoma cells to promote scattering and invasion. Mol Cancer Res 6(10):1521-1533.

Cleary MP, Grossmann ME. 2009. Minireview: Obesity and breast cancer: the estrogen connection. Endocrinology 150(6):25372542.

Collado-Hidalgo A, Bower JE, Ganz PA, Cole SW, Irwin MR. 2006. Inflammatory biomarkers for persistent fatigue in breast cancer survivors. Clin Cancer Res 12(9):2759-2766.

Connelly L, Barham W, Onishko HM, Sherrill T, Chodosh LA, Blackwell TS, Yull FE. 2011. Inhibition of NF-kappa B activity in mammary epithelium increases tumor latency and decreases tumor burden. Oncogene 30(12):1402-1412.

Coussens LM, Werb Z. 2002. Inflammation and cancer. Nature 420(6917):860-867.

Culig Z. 2011. Cytokine disbalance in common human cancers. Biochim Biophys Acta 1813(2):308-314.

D’Cruz CM, Moody SE, Master SR, Hartman JL, Keiper EA, Imielinski MB, Chodosh LA. 2002. Persistent parity-induced changes in growth factors, TGF-beta3, and differentiation in the rodent mammary gland. Mol Endocrinol 16(9):20342051.

D'Esposito V, Passaretti F, Hammarstedt A, Liguoro D, Terracciano D, Molea G, Formisano P. 2012. Adipocyte-released insulin-like growth factor-1 is regulated by glucose and fatty acids and controls breast cancer cell growth in vitro. Diabetologia 55(10):2811-2822.

Dai X-M, Ryan GR, Hapel AJ, Dominguez MG, Russell RG, Kapp S, Stanley ER. 2002. Targeted disruption of the mouse colony-stimulating factor 1 receptor gene results in osteopetrosis, mononuclear phagocyte deficiency, increased primitive progenitor cell frequencies, and reproductive defects. Blood 99(1):111-120.
Dave H, Trivedi S, Shah M, Shukla S. 2011. Transforming growth factor beta 2: a predictive marker for breast cancer. Indian J Exp Biol 49(11):879-887.

De Luca A, Gallo M, Aldinucci D, Ribatti D, Lamura L, D'Alessio A, Normanno N. 2011. Role of the EGFR ligand/ receptor system in the secretion of angiogenic factors in mesenchymal stem cells. J Cell Physiol 226(8):2131-2138.

De Luca A, Lamura L, Gallo M, Maffia V, Normanno N. 2012. Mesenchymal stem cell-derived interleukin-6 and vascular endothelial growth factor promote breast cancer cell migration. J Cell Biochem 113(11):3363-3370.

Desmedt C, Piette F, Loi S, Wang Y, Lallemand F, Haibe-Kains B, Sotiriou C. 2007. Strong time dependence of the 76-gene prognostic signature for node-negative breast cancer patients in the TRANSBIG multicenter independent validation series. Clin Cancer Res 13(11):3207-3214.

Dieudonne M-N, Bussiere M, Dos Santos E, Leneveu M-C, Giudicelli Y, Pecquery R. 2006. Adiponectin mediates antiproliferative and apoptotic responses in human MCF7 breast cancer cells. Biochem Biophys Res Commun 345(1):271279.

Dinarello CA. 1996. Biologic basis for interleukin-1 in disease. Blood 87(6):2095-2147.

Donato NJ, Klostergaard J. 2004. Distinct stress and cell destruction pathways are engaged by TNF and ceramide during apoptosis of MCF-7 cells. Exp Cell Res 294(2):523-533.

Donovan J, Slingerland J. 2000. Transforming growth factorbeta and breast cancer: Cell cycle arrest by transforming growth factor-beta and its disruption in cancer. Breast Cancer Res 2(2):116-124.

Duffy MJ, Maguire TM, Hill A, McDermott E, O'Higgins N. 2000. Metalloproteinases: role in breast carcinogenesis, invasion and metastasis. Breast Cancer Res 2(4):252-257.

Dunn LK, Mohammad KS, Fournier PGJ, McKenna CR, Davis HW, Niewolna M, Guise TA. 2009. Hypoxia and TGF-beta drive breast cancer bone metastases through parallel signaling pathways in tumor cells and the bone microenvironment. PloS One 4(9):e6896.

Elenbaas B, Spirio L, Koerner F, Fleming MD, Zimonjic DB, Donaher JL, Weinberg RA. 2001. Human breast cancer cells generated by oncogenic transformation of primary mammary epithelial cells. Genes Dev 15(1):50-65.

Ernst M, Putoczki TL. 2012. Stat3: linking inflammation to (gastrointestinal) tumourigenesis. Clin Exp Pharmacol Physiol 39(8):711-718.

Ewan KBR, Oketch-Rabah HA, Ravani SA, Shyamala G, Moses HL, Barcellos-Hoff MH. 2005. Proliferation of estrogen receptor-alpha-positive mammary epithelial cells is restrained by transforming growth factor-beta1 in adult mice. Am J Pathol 167(2):409-417.

Faggioni R, Fantuzzi G, Fuller J, Dinarello CA, Feingold KR, Grunfeld C. 1998. IL-1 beta mediates leptin induction during inflammation. Am J Physiol 274(1 Pt 2):R204-R208.

Favaro E, Lord S, Harris AL, Buffa FM. 2011. Gene expression and hypoxia in breast cancer. Genome Med 3(8):55.

Fehniger TA, Cooper MA, Caligiuri MA. 2002. Interleukin-2 and interleukin-15: immunotherapy for cancer. Cytokine Growth Factor Rev 13(2):169-183.

Feng X-H, Liang Y-Y, Liang M, Zhai W, Lin X. 2002. Direct interaction of c-Myc with Smad2 and Smad3 to inhibit TGFbeta-mediated induction of the CDK inhibitor p15(Ink4B). Mol Cell 9(1):133-143.

Figueroa JD, Flanders KC, Garcia-Closas M, Anderson WF, Yang XR, Matsuno RK, Sherman ME. 2010. Expression of TGF-beta signaling factors in invasive breast cancers: 
relationships with age at diagnosis and tumor characteristics. Breast Cancer Res Treat 121(3):727-735.

Franco-Barraza J, Valdivia-Silva JE, Zamudio-Meza H, Castillo A, García-Zepeda EA, Benítez-Bribiesca L, Meza I. 2010. Actin cytoskeleton participation in the onset of IL-1beta induction of an invasive mesenchymal-like phenotype in epithelial MCF-7 cells. Arch Med Res 41(3):170-181.

Fujita Y, Murakami M, Ogawa Y, Masuzaki H, Tanaka M, Ozaki S, Mimori T. 2002. Leptin inhibits stress-induced apoptosis of T lymphocytes. Clin Exp Immunol 128(1):21-26.

Gangemi S, Minciullo P, Adamo B, Franchina T, Ricciardi GRR, Ferraro M, Adamo V. 2012. Clinical significance of circulating interleukin-23 as a prognostic factor in breast cancer patients. J Cell Biochem 113(6):2122-2125.

Glasgow E, Mishra L. 2008. Transforming growth factor-beta signaling and ubiquitinators in cancer. Endocr Relat Cancer 15(1):59-72.

Glinka Y, Prud'homme, G. J. 2008. Neuropilin-1 is a receptor for transforming growth factor beta-1, activates its latent form, and promotes regulatory $\mathrm{T}$ cell activity. J Leukoc Biol 84(1):302-310.

Goldberg JE, Schwertfeger KL. 2010. Proinflammatory cytokines in breast cancer: mechanisms of action and potential targets for therapeutics. Curr Drug Targets 11(9):1133-1146.

Goldstein RH, Reagan MR, Anderson K, Kaplan DL, Rosenblatt M. 2010. Human bone marrow-derived MSCs can home to orthotopic breast cancer tumors and promote bone metastasis. Cancer Res 70(24):10044-10050.

Grau AM, Wen W, Ramroopsingh DS, Gao Y-T, Zi J, Cai Q, Zheng W. 2008. Circulating transforming growth factor-beta-1 and breast cancer prognosis: results from the Shanghai Breast Cancer Study. Breast Cancer Res Treat 112(2):335-341.

Grivennikov SI, Greten FR, Karin M. 2010. Immunity, inflammation, and cancer. Cell 140(6):883-899.

Guo Y, Xu F, Lu T, Duan Z, Zhang Z. 2012. Interleukin-6 signaling pathway in targeted therapy for cancer. Cancer Treat Rev 38(7):904-910.

Hamed EA, Zakhary MM, Maximous DW. 2012. Apoptosis, angiogenesis, inflammation, and oxidative stress: basic interactions in patients with early and metastatic breast cancer. J Cancer Res Clin Oncol 138(6):999-1009.

Hamidullah, Changkija B, Konwar R. 2011. Role of interleukin10 in breast cancer. Breast Cancer Res Treat 133(1):11-21.

Harvey SB, Wessely S, Kuh D, Hotopf M. 2009. The relationship between fatigue and psychiatric disorders: evidence for the concept of neurasthenia. J Psychosom Res 66(5):445454.

He D, Li H, Yusuf N, Elmets CA, Li J, Mountz JD, Xu H. 2010. IL-17 promotes tumor development through the induction of tumor promoting microenvironments at tumor sites and myeloidderived suppressor cells. J Immunol 184(5):2281-2288.

Heldin C-H, Landström M, Moustakas A. 2009. Mechanism of TGF-beta signaling to growth arrest, apoptosis, and epithelialmesenchymal transition. Curr Opin Cell Biol 21(2):166-176.

Honma S, Shimodaira K, Shimizu Y, Tsuchiya N, Saito H, Yanaihara T, Okai T. 2002. The influence of inflammatory cytokines on estrogen production and cell proliferation in human breast cancer cells. Endocr J 49(3):371-377.

Hou W-K, Xu Y-X, Yu T, Zhang L, Zhang W-W, Fu C-L, Chen L. 2007. Adipocytokines and breast cancer risk. Chin Med J 120(18):1592-1596.

Hsing C-H, Cheng H-C, Hsu Y-H, Chan C-H, Yeh C-H, Li C-F, Chang M-S. 2012. Upregulated IL-19 in breast cancer promotes tumor progression and affects clinical outcome. Clin Cancer Res 18(3):713-725.
Hsu Y-H, Hsing C-H, Li C-F, Chan C-H, Chang M-C, Yan J-J, Chang M-S. 2012. Anti-IL-20 monoclonal antibody suppresses breast cancer progression and bone osteolysis in murine models. J Immunol 188(4):1981-1991.

Hu X, Juneja SC, Maihle NJ, Cleary MP. 2002. Leptin-a growth factor in normal and malignant breast cells and for normal mammary gland development. J Natl Cancer Inst 94(22):1704-1711.

Humphreys RC, Hennighausen L. 2000. Transforming growth factor alpha and mouse models of human breast cancer. Oncogene 19(8):1085-1091.

Hung S-P, Ho JH, Shih Y-R. V, Lo T, Lee OK. 2012a. Hypoxia promotes proliferation and osteogenic differentiation potentials of human mesenchymal stem cells. J Orthop Res 30(2): 260-266.

Hung S-P, Yang M-H, Tseng K-F, Lee OK. 2012b. Hypoxiainduced secretion of TGF-beta 1 in mesenchymal stem cell promotes breast cancer cell progression. Cell Transplant 22(10):1869-1882.

Iguchi M, Aiba S, Yoshino Y, Tagami H. 2001. Human follicular papilla cells carry out nonadipose tissue production of leptin. J Invest Dermatol 117(6):1349-1356.

Iliopoulos D, Hirsch HA, Struhl K. 2009. An epigenetic switch involving NF-kappaB, Lin28, Let-7 MicroRNA, and IL6 links inflammation to cell transformation. Cell 139(4):693706.

Iliopoulos D, Hirsch HA, Wang G, Struhl K. 2011. Inducible formation of breast cancer stem cells and their dynamic equilibrium with non-stem cancer cells via IL6 secretion. Proc Natl Acad Sci U S A 108(4):1397-1402.

Iliopoulos D, Jaeger SA, Hirsch HA, Bulyk ML, Struhl K. 2010. STAT3 activation of miR-21 and miR-181b-1 via PTEN and CYLD are part of the epigenetic switch linking inflammation to cancer. Mol Cell 39(4):493-506.

Imamura T, Hikita A, Inoue Y. 2012. The roles of TGF- $\beta$ signaling in carcinogenesis and breast cancer metastasis. Breast Cancer 19(2):118-124.

Inman GJ. 2011. Switching TGF $\beta$ from a tumor suppressor to a tumor promoter. Curr Opin Genet Dev 21(1):93-99.

Irahara N, Miyoshi Y, Taguchi T, Tamaki Y, Noguchi S. 2006. Quantitative analysis of aromatase mRNA expression derived from various promoters (I.4, I.3, PII and I.7) and its association with expression of TNF-alpha, IL-6 and COX-2 mRNAs in human breast cancer. Int $\mathbf{J}$ of Cancer 118(8): 1915-1921.

Ivanović V, Dedović-Tanić N, Milovanović Z, Lukić S, Nikolić S, Baltić V, Dimitrijević B. 2009. Quantification of transforming growth factor beta 1 levels in metastatic axillary lymph node tissue extracts from breast cancer patients: a new specimen source. Anal Quant Cytol Histol 31(5):288-295.

Ivshina AV, George J, Senko O, Mow B, Putti TC, Smeds J, Miller LD. 2006. Genetic reclassification of histologic grade delineates new clinical subtypes of breast cancer. Cancer Res 66(21):10292-10301.

Jain P, Alahari SK. 2011. Breast cancer stem cells: a new challenge for breast cancer treatment. Front Biosci 16:1824-1832.

Jardé T, Caldefie-Chézet F, Damez M, Mishellany F, PenaultLlorca F, Guillot J, Vasson MP. 2008. Leptin and leptin receptor involvement in cancer development: a study on human primary breast carcinoma. Oncol Rep 19(4):905-911.

Jin L, Yuan RQ, Fuchs A, Yao Y, Joseph A, Schwall R, Rosen EM. 1997. Expression of interleukin-1beta in human breast carcinoma. Cancer 80(3):421-434.

Joffroy CM, Buck MB, Stope MB, Popp SL, Pfizenmaier K, Knabbe C. 2010. Antiestrogens induce transforming growth 
factor beta-mediated immunosuppression in breast cancer. Cancer Res 70(4):1314-1322.

Joshi A, Cao D. 2010. TGF-beta signaling, tumor microenvironment and tumor progression: the butterfly effect. Front Biosci 15:180-194.

Juárez P, Guise TA. 2010. Tgf-Beta pathway as a therapeutic target in bone metastases. Curr Pharm Des 16(11):13011312.

Jung Y-J, Isaacs JS, Lee S, Trepel J, Neckers L. 2003. IL-1betamediated up-regulation of HIF-1alpha via an NFkappaB/ COX-2 pathway identifies HIF-1 as a critical link between inflammation and oncogenesis. FASEB J 17(14):2115-2117.

Kalluri R, Weinberg RA. 2009. The basics of epithelialmesenchymal transition. J Clin Invest 119(6):1420-1428.

Kamel M, Shouman S, El-Merzebany M, Kilic G, Veenstra T, Saeed M, Salama S. 2012. Effect of tumour necrosis factoralpha on estrogen metabolic pathways in breast cancer cells. J Cancer 3:310-321.

Kang JH, Lee YY, Yu BY, Yang B-S, Cho K-H, Yoon DK, Roh YK. 2005. Adiponectin induces growth arrest and apoptosis of MDA-MB-231 breast cancer cell. Arch Pharm Res 28(11): 1263-1269.

Karayiannakis AJ, Syrigos KN, Polychronidis A, Pitiakoudis M, Bounovas A, Simopoulos K. 2001. Serum levels of tumor necrosis factor-alpha and nutritional status in pancreatic cancer patients. Anticancer Res 21(2B):1355-1358.

Karin M, Greten FR. 2005. NF-kappaB: linking inflammation and immunity to cancer development and progression. Nat Rev Immunol 5(10):749-759.

Karnoub AE, Dash AB, Vo AP, Sullivan A, Brooks MW, Bell GW, Weinberg RA. 2007. Mesenchymal stem cells within tumour stroma promote breast cancer metastasis. Nature 449(7162):557-563.

Kelly RJ, Morris JC. 2010. Transforming growth factor-beta: a target for cancer therapy. J Immunotoxicol 7(1):15-26.

Kim KY, Jeong SY, Won J, Ryu PD, Nam MJ. 2001. Induction of angiogenesis by expression of soluble type II transforming growth factor-beta receptor in mouse hepatoma. J Biol Chem 276(42):38781-38786.

Kluger HM, Dolled-Filhart M, Rodov S, Kacinski BM, Camp RL, Rimm DL. 2004. Macrophage colony-stimulating factor1 receptor expression is associated with poor outcome in breast cancer by large cohort tissue microarray analysis. Clin Cancer Res 10(1 Pt 1):173-177.

Knüpfer H, Preiss R. 2007. Significance of interleukin-6 (IL-6) in breast cancer (review). Breast Cancer Res Treat 102(2): 129-135.

Kojima Y, Acar A, Eaton EN, Mellody KT, Scheel C, BenPorath I, Orimo A. 2010. Autocrine TGF-beta and stromal cell-derived factor-1 (SDF-1) signaling drives the evolution of tumor-promoting mammary stromal myofibroblasts. Proc Natl Acad Sci U S A 107(46):20009-20014.

Koli KM, Arteaga CL. 1997. Predominant cytosolic localization of type II transforming growth factor beta receptors in human breast carcinoma cells. Cancer Res 57(5):970-977.

Korkaya H, Kim G-I, Davis A, Malik F, Henry NL, Ithimakin S, Wicha MS. 2012. Activation of an IL6 inflammatory loop mediates trastuzumab resistance in HER $2+$ breast cancer by expanding the cancer stem cell population. Mol Cell 47(4): 570-584.

Korkaya H, Liu S, Wicha MS. 2011. Review series Breast cancer stem cells, cytokine networks, and the tumor microenvironment. J Clin Invest 121(10):3804-3809.

Kozłowski L, Zakrzewska I, Tokajuk P, Wojtukiewicz MZ. 2003. Concentration of interleukin-6 (IL-6), interleukin-8
(IL-8) and interleukin-10 (IL-10) in blood serum of breast cancer patients. Rocz Akad Med Białymst 48:82-84.

Krishnamurthy P, Schuetz JD. 2006. Role of ABCG2/BCRP in biology and medicine. Ann Rev Pharmacol Toxicol 46:381410.

Langowski JL, Zhang X, Wu L, Mattson JD, Chen T, Smith K, Oft M. 2006. IL-23 promotes tumour incidence and growth. Nature 442(7101):461-465.

Laud K, Gourdou I, Pessemesse L, Peyrat JP, Djiane J. 2002. Identification of leptin receptors in human breast cancer: functional activity in the T47-D breast cancer cell line. Mol Cell Endocrinol 188(1-2):219-226.

Laverty HG, Wakefield LM, Occleston NL, O'Kane S, Ferguson MWJ. 2009. TGF-beta3 and cancer: a review. Cytokine Growth Factor Rev 20(4):305-317.

Leek RD, Landers R, Fox SB, Ng F, Harris AL, Lewis CE. 1998. Association of tumour necrosis factor alpha and its receptors with thymidine phosphorylase expression in invasive breast carcinoma. Br J Cancer 77(12):2246-2251.

Lewis AM, Varghese S, Xu H, Alexander HR. 2006. Interleukin1 and cancer progression: the emerging role of interleukin-1 receptor antagonist as a novel therapeutic agent in cancer treatment. J Transl Med 4:48.

Lin EY, Nguyen AV, Russell RG, Pollard JW. 2001. Colonystimulating factor 1 promotes progression of mammary tumors to malignancy. J Exp Med 193(6):727-740.

Lin S, Yang J, Elkahloun AG, Bandyopadhyay A, Wang L, Cornell JE, Sun L-Z. 2012. Attenuation of TGF- $\beta$ signaling suppresses premature senescence in a p21-dependent manner and promotes oncogenic Ras-mediated metastatic transformation in human mammary epithelial cells. Mol Biol Cell 23(8):1569-1581.

Lis CG, Gupta D, Grutsch JF. 2008. The relationship between insomnia and patient satisfaction with quality of life in cancer. Support Care Cancer 16(3):261-266.

Liu J, Liao S, Diop-frimpong B, Chen W, Goel S, Naxerova K, Xu L. 2012a. TGF- $\beta$ blockade improves the distribution and efficacy of therapeutics in breast carcinoma by normalizing the tumor stroma. Proc Natl Acad Sci U S A 109(41):1661816623.

Liu L, Mills PJ, Rissling M, Fiorentino L, Natarajan L, Dimsdale JE, Ancoli-Israel S. 2012b. Fatigue and sleep quality are associated with changes in inflammatory markers in breast cancer patients undergoing chemotherapy. Brain Behav Immun 26(5):706-713.

Lyon DE, McCain NL, Walter J, Schubert C. 2008. Cytokine comparisons between women with breast cancer and women with a negative breast biopsy. Nurs Res 57(1):51-58.

Maher MG, Sapi E, Turner B, Gumbs A, Perrotta PL, Carter D, Haffty BG. 1998. Prognostic significance of colony-stimulating factor receptor expression in ipsilateral breast cancer recurrence. Clin Cancer Res 4(8):1851-1856.

Malekshah OM, Lage H, Bahrami AR, Afshari JT, Behravan J. 2012. PXR and NF- $\kappa$ B correlate with the inducing effects of IL-1 $\beta$ and TNF- $\alpha$ on ABCG2 expression in breast cancer cell lines. Eur J Pharm Sci 47(2):474-480.

Mani SA, Guo W, Liao M-J, Eaton EN, Ayyanan A, Zhou AY, Weinberg RA. 2008. The epithelial-mesenchymal transition generates cells with properties of stem cells. Cell 133(4):704715.

Martín-Romero C, Santos-Alvarez J, Goberna R, SánchezMargalet V. 2000. Human leptin enhances activation and proliferation of human circulating $\mathrm{T}$ lymphocytes. Cell Immunol 199(1):15-24.

Massagué J. 2008. TGFbeta in Cancer. Cell 134(2):215-230. 
Merendino RA, Arena A, Capozza AB, Chillemi S, Mesiti M. 1996. Serum levels of interleukin-10 in patients affected by breast cancer. Immunol Lett 53(1):59-60.

Meulmeester E, Ten Dijke P. 2011. The dynamic roles of TGF$\beta$ in cancer. J Pathol 223(2):205-218.

Miles DW, Happerfield LC, Naylor MS, Bobrow LG, Rubens RD, Balkwill FR. 1994. Expression of tumour necrosis factor (TNF alpha) and its receptors in benign and malignant breast tissue. Int J Cancer 56(6):777-782.

Miller LD, Smeds J, George J, Vega VB, Vergara L, Ploner A, Bergh J. 2005. An expression signature for p53 status in human breast cancer predicts mutation status, transcriptional effects, and patient survival. Proc Natl Acad Sci U S A 102(38):13550-13555.

Miller LJ, Kurtzman SH, Anderson K, Wang Y, Stankus M, Renna M, Kreutzer DL. 2000. Interleukin-1 family expression in human breast cancer: interleukin-1 receptor antagonist. Cancer Invest 18(4):293-302.

Mills PJ, Parker B, Dimsdale JE, Sadler GR, Ancoli-Israel S. 2005. The relationship between fatigue and quality of life and inflammation during anthracycline-based chemotherapy in breast cancer. Biol Psychol 69(1):85-96.

Miyoshi Y, Funahashi T, Kihara S, Taguchi T, Tamaki Y, Matsuzawa Y, Noguchi S. 2003. Association of serum adiponectin levels with breast cancer risk. Clin Cancer Res 9(15):5699-5704.

Molloy AP, Martin FT, Dwyer RM, Griffin TP, Murphy M, Barry FP, Kerin MJ. 2009. Mesenchymal stem cell secretion of chemokines during differentiation into osteoblasts, and their potential role in mediating interactions with breast cancer cells. Int J Cancer 124(2):326-332.

Moore KW, de Waal Malefyt R, Coffman RL, O'Garra A. 2001. Interleukin-10 and the interleukin-10 receptor. Ann Rev Immunol 19:683-765.

Moore KW, O'Garra A, de Waal Malefyt R, Vieira P, Mosmann TR. 1993. Interleukin-10. Ann Rev Immunol 11:165-190.

Mor G, Yue W, Santen RJ, Gutierrez L, Eliza M, Berstein LM, Naftolin F. 1998. Macrophages, estrogen and the microenvironment of breast cancer. J Steroid Biochem Mol Biol 67(5-6):403-411.

Morandi A, Barbetti V, Riverso M, Dello Sbarba P, Rovida E. 2011. The colony-stimulating factor-1 (CSF-1) receptor sustains ERK1/2 activation and proliferation in breast cancer cell lines. PloS One 6(11):e27450.

Mosaffa F, Lage H, Afshari JT, Behravan J. 2009. Interleukin-1 beta and tumor necrosis factor-alpha increase ABCG2 expression in MCF-7 breast carcinoma cell line and its mitoxantrone-resistant derivative, MCF-7/MX. Inflamm Res 58(10):669-676.

Mumm JB, Emmerich J, Zhang X, Chan I, Wu L, Mauze S, Oft M. 2011. IL-10 elicits IFN $\gamma$-dependent tumor immune surveillance. Cancer Cell 20(6):781-796.

Naber HPH, Wiercinska E, Ten Dijke P, van Laar T. 2011. Spheroid assay to measure TGF- $\beta$-induced invasion. $\mathrm{J}$ Vis Exp (57):1-7.

Naik MU, Naik TU, Suckow AT, Duncan MK, Naik UP. 2008. Attenuation of junctional adhesion molecule-A is a contributing factor for breast cancer cell invasion. Cancer Res 68(7):2194-2203.

Nariţa D, Seclaman E, Ursoniu S, Ilina R, Cireap N, Anghel A. 2011. Expression of CCL18 and interleukin- 6 in the plasma of breast cancer patients as compared with benign tumor patients and healthy controls. Rom J Morphol Embryol 52(4):1261-1267.
Nicolini A, Carpi A. 2008. Immune manipulation of advanced breast cancer: an interpretative model of the relationship between immune system and tumor cell biology. Med Res Rev 29(3):436-471.

Nicolini A, Carpi A, Rossi G. 2006. Cytokines in breast cancer. Cytokine Growth Factor Rev 17(5):325-337.

Novitskiy SV, Pickup MW, Gorska AE, Owens P, Chytil A, Aakre M, Moses HL. 2011. TGF- $\beta$ receptor II loss promotes mammary carcinoma progression by Th17 dependent mechanisms. Cancer Discov 1(5):430-441.

O'brien SN, Welter BH, Price TM. 1999. Presence of leptin in breast cell lines and breast tumors. Biochem Biophys Res Commun 259(3):695-698.

Opp MR. 2005. Cytokines and sleep. Sleep Med Rev 9(5):355364.

Orimo A, Weinberg RA. 2006. Stromal fibroblasts in cancer: a novel tumor-promoting cell type. Cell Cycle 5(15):15971601.

Ostman A, Augsten M. 2009. Cancer-associated fibroblasts and tumor growth-bystanders turning into key players. Curr Opin Genet Dev 19(1):67-73.

Otero M, Lago R, Gómez R, Lago F, Gómez-Reino JJ, Gualillo O. 2006. Leptin: a metabolic hormone that functions like a proinflammatory adipokine. Drug News Perspect 19(1): 21-26.

Ouchi N, Parker JL, Lugus JJ, Walsh K. 2011. Adipokines in inflammation and metabolic disease. Nat Rev Immunol 11(2):85-97.

Pantschenko AG, Pushkar I, Anderson KH, Wang Y, Miller LJ, Kurtzman SH, Kreutzer DL. 2003. The interleukin-1 family of cytokines and receptors in human breast cancer: implications for tumor progression. Int J Oncol 23(2):269-284.

Patel LR, Camacho DF, Shiozawa Y, Pienta KJ. 2012. Mechanisms of cancer cell metastasis to the bone: a multistep process. Future Oncol 7(11):1285-1297.

Perk J, Iavarone A, Benezra R. 2005. Id family of helix-loophelix proteins in cancer. Nat Rev Cancer 5(8):603-614.

Perrier S, Caldefie-Chézet F, Vasson M-P. 2009. IL-1 family in breast cancer: potential interplay with leptin and other adipocytokines. FEBS Lett 583(2):259-265.

Peter R, Stefania M, Ping LJ, Marcel Z, Josef B, Markus H. 2013. Primary prophylactic colony-stimulating factors for the prevention of chemotherapy-induced febrile neutropenia in breast cancer patients. Cochrane Database Syst Rev 10: CD007913.

Pfeilschifter J, Köditz R, Pfohl M, Schatz H. 2002. Changes in proinflammatory cytokine activity after menopause. Endocrine Rev 23(1):90-119.

Podsypanina K, Du Y-CN, Jechlinger M, Beverly LJ, Hambardzumyan D, Varmus H. 2008. Seeding and propagation of untransformed mouse mammary cells in the lung. Science 321(5897):1841-1844.

Pradhan M, Bembinster LA, Baumgarten SC, Frasor J. 2010. Proinflammatory cytokines enhance estrogen-dependent expression of the multidrug transporter gene ABCG2 through estrogen receptor and $\mathrm{NF}$ \{kappa $\} \mathrm{B}$ cooperativity at adjacent response elements. J Biol Chem 285(41):3110031106.

Price DJ, Miralem T, Jiang S, Steinberg R, Avraham H. 2001. Role of vascular endothelial growth factor in the stimulation of cellular invasion and signaling of breast cancer cells. Cell Growth Differ 12(3):129-135.

Rafiq S, Stevens K, Hurst AJ, Murray A, Henley W, Weedon MN, Frayling TM. 2007. Common genetic variation in the gene encoding interleukin-1-receptor antagonist (IL-1RA) is 
associated with altered circulating IL-1RA levels. Genes Immun 8(4):344-351.

Raison CL, Rye DB, Woolwine BJ, Vogt GJ, Bautista BM, Spivey JR, Miller AH. 2010. Chronic interferon-alpha administration disrupts sleep continuity and depth in patients with hepatitis $\mathrm{C}$ : association with fatigue, motor slowing, and increased evening cortisol. Biol Psychiatry 68(10):942-949.

Reichlin S, Chen G, Nicolson M. 2000. Blood to brain transfer of leptin in normal and interleukin-1beta-treated male rats. Endocrinology 141(6):1951-1954.

Reyes-Gibby CC, Wu X, Spitz M, Kurzrock R, Fisch M, Bruera E, Shete S. 2008. Molecular epidemiology, cancer-related symptoms, and cytokines pathway. Lancet Oncol 9(8):777785.

Sabe H. 2011. Cancer early dissemination: cancerous epithelialmesenchymal transdifferentiation and transforming growth factor $\beta$ signalling. J Biochem 149(6):633-639.

Sasser AK, Sullivan NJ, Studebaker AW, Hendey LF, Axel AE, Hall BM. 2007. Interleukin-6 is a potent growth factor for ER-alpha-positive human breast cancer. FASEB J 21(13): 3763-3770.

Scholl SM, Pallud C, Beuvon F, Hacene K, Stanley ER, Rohrschneider L, Lidereau R. 1994. Anti-colony-stimulating factor-1 antibody staining in primary breast adenocarcinomas correlates with marked inflammatory cell infiltrates and prognosis. J Natl Cancer Inst 86(2):120-126.

Schultz SL, Dalton SO, Christensen J, Carlsen K, Ross L, Johansen C. 2011. Factors correlated with fatigue in breast cancer survivors undergoing a rehabilitation course, Denmark, 2002-2005. Psycho Oncol 20(4):352-360.

Serra R, Easter SL, Jiang W, Baxley SE. 2011. Wnt5a as an effector of TGF $\beta$ in mammary development and cancer. J Mammary Gland Biol Neoplasia 16(2):157-167.

Shangguan L, Ti X, Krause U, Hai B, Zhao Y, Yang Z, Liu F. 2012. Inhibition of TGF- $\beta /$ Smad signaling by BAMBI blocks differentiation of human mesenchymal stem cells to carcinoma-associated fibroblasts and abolishes their protumor effects. Stem Cells 30(12):2810-2819.

Sheen-Chen SM, Chen WJ, Eng HL, Chou FF. 1997. Serum concentration of tumor necrosis factor in patients with breast cancer. Breast Cancer Res Treat 43(3):211-215.

Sherr CJ, Rettenmier CW, Sacca R, Roussel MF, Look AT, Stanley ER. 1985. The c-fms proto-oncogene product is related to the receptor for the mononuclear phagocyte growth factor, CSF-1. Cell 41(3):665-676.

Shi Z, Yang W-M, Chen L-P, Yang D-H, Zhou Q, Zhu J, Huang R-P. 2012. Enhanced chemosensitization in multidrug-resistant human breast cancer cells by inhibition of IL-6 and IL-8 production. Breast Cancer Res Treat 135(3): 737-747.

Simeone A-M, Nieves-Alicea R, McMurtry VC, Colella S, Krahe R, Tari AM. 2007. Cyclooxygenase-2 uses the protein kinase C/interleukin-8/urokinase-type plasminogen activator pathway to increase the invasiveness of breast cancer cells. Int J Oncol 30(4):785-792.

Singer CF, Kronsteiner N, Hudelist G, Marton E, Walter I, Kubista M, Kubista E. 2003. Interleukin 1 system and sex steroid receptor expression in human breast cancer: interleukin 1alpha protein secretion is correlated with malignant phenotype. Clin Cancer Res 9(13):4877-4883.

Singh G, Singh SK, König A, Reutlinger K, Nye MD, Adhikary T, Ellenrieder V. 2010. Sequential activation of NFAT and cMyc transcription factors mediates the TGF-beta switch from a suppressor to a promoter of cancer cell proliferation. J Biol Chem 285(35):27241-27250.
Sisirak V, Faget J, Gobert M, Goutagny N, Vey N, Treilleux I, Bendriss-Vermare N. 2012. Impaired IFN- $\alpha$ production by plasmacytoid dendritic cells favors regulatory T-cell expansion that may contribute to breast cancer progression. Cancer Res 72(20):5188-5197.

Snoussi K, Mahfoudh W, Bouaouina N, Ahmed SB, Helal AN, Chouchane L. 2006. Genetic variation in IL-8 associated with increased risk and poor prognosis of breast carcinoma. Hum Immunol 67(1-2):13-21.

Sotiriou C, Wirapati P, Loi S, Harris A, Fox S, Smeds J, Delorenzi M. 2006. Gene expression profiling in breast cancer: understanding the molecular basis of histologic grade to improve prognosis. J Natl Cancer Inst 98(4):262-272.

Srabovic N, Mujagic Z, Mujanovic-mustedanagic J, Muminovic Z, Softic A, Begic L. 2011. Interleukin 13 expression in the primary breast cancer tumor tissue. Biochem Medica 21(2): 131-138.

Starkweather AR, Lyon DE, Schubert CM. 2013. Pain and inflammation in women with early-stage breast cancer prior to induction of chemotherapy. Biol Res Nurs 15(2):234-241.

Studebaker AW, Storci G, Werbeck JL, Sansone P, Sasser AK, Tavolari S, Hall BM. 2008. Fibroblasts isolated from common sites of breast cancer metastasis enhance cancer cell growth rates and invasiveness in an interleukin-6-dependent manner. Cancer Res 68(21):9087-9095.

Sullivan NJ, Sasser AK, Axel AE, Vesuna F, Raman V, Ramirez N, Hall BM. 2009. Interleukin-6 induces an epithelialmesenchymal transition phenotype in human breast cancer cells. Oncogene 28(33):2940-2947.

Swain SL. 1991. Lymphokines and the immune response: the central role of interleukin-2. Curr Opin Immunol 3(3):304310.

Taube JH, Herschkowitz JI, Komurov K, Zhou AY, Gupta S, Yang J, Mani SA. 2010. Core epithelial-to-mesenchymal transition interactome gene-expression signature is associated with claudin-low and metaplastic breast cancer subtypes. Proc Natl Acad Sci U S A 107(35):15449-15454.

Tian M, Schiemann WP. 2010. PGE2 receptor EP2 mediates the antagonistic effect of COX-2 on TGF-beta signaling during mammary tumorigenesis. FASEB J 24(4):1105-1116.

Tilg H, Moschen AR. 2006. Adipocytokines: mediators linking adipose tissue, inflammation and immunity. Nat Rev Immunol 6(10):772-783.

Van de Vijver MJ, He YD, van't Veer LJ, Dai H, Hart AAM, Voskuil DW, Bernards R. 2002. A gene-expression signature as a predictor of survival in breast cancer. N Engl J Med 347(25):1999-2009.

Van den Beuken-van Everdingen MHJ, de Rijke JM, Kessels AG, Schouten HC, van Kleef M, Patijn J. 2007. High prevalence of pain in patients with cancer in a large populationbased study in The Netherlands. Pain 132(3):312-320.

Van der Auwera I, Van Laere SJ, Van den Eynden GG, Benoy I, van Dam P, Colpaert CG, Dirix LY. 2004. Increased angiogenesis and lymphangiogenesis in inflammatory versus noninflammatory breast cancer by real-time reverse transcriptase-PCR gene expression quantification. Clin Cancer Res 10(23):7965-7971.

Vazquez-Martin A, Colomer R, Menendez JA. 2007. Protein array technology to detect HER2 (erbB-2)-induced "cytokine signature" in breast cancer. Eur J Cancer 43(7):11171124.

Veldhoen M, Hocking RJ, Atkins CJ, Locksley RM, Stockinger B. 2006. TGFbeta in the context of an inflammatory cytokine milieu supports de novo differentiation of IL-17-producing $\mathrm{T}$ cells. Immunity 24(2):179-189. 
Vgontzas AN, Papanicolaou DA, Bixler EO, Kales A, Tyson K, Chrousos GP. 1997. Elevation of plasma cytokines in disorders of excessive daytime sleepiness: role of sleep disturbance and obesity. J Clin Endocrinol Metab 82(5):1313-1316.

Vincent T, Neve EPA, Johnson JR, Kukalev A, Rojo F, Albanell J, Fuxe J. 2009. A SNAIL1-SMAD3/4 transcriptional repressor complex promotes TGF- $\beta$ mediated epithelialmesenchymal transition. Nat Cell Biol 11(8):943-950.

Voulgari A, Pintzas A. 2009. Epithelial-mesenchymal transition in cancer metastasis: mechanisms, markers and strategies to overcome drug resistance in the clinic. Biochim Biophys Acta 1796(2):75-90.

Walter M, Liang S, Ghosh S, Hornsby PJ, Li R. 2009. Interleukin 6 secreted from adipose stromal cells promotes migration and invasion of breast cancer cells. Oncogene 28(30): 2745-2755.

Wang F, Liu H, Liu S, Tang S, Yang L, Feng G. 2005. SHP-2 promoting migration and metastasis of MCF-7 with loss of Ecadherin, dephosphorylation of FAK and secretion of MMP-9 induced by IL-1beta in vivo and in vitro. Breast Cancer Res Treat 89(1):5-14.

Wang Y, Lui W-Y. 2012. Transforming growth factor- $\beta 1$ attenuates junctional adhesion molecule-A and contributes to breast cancer cell invasion. Eur J Cancer 48(18):3475-3487.

Weigert A, Tzieply N, von Knethen A, Johann AM, Schmidt H, Geisslinger G, Brüne B. 2007. Tumor cell apoptosis polarizes macrophages role of sphingosine-1-phosphate. Mol Biol Cell 18(10):3810-3819.

Wendt MK, Allington TM, Schiemann WP. 2009. Mechanisms of the epithelial-mesenchymal transition by TGF-beta. Future Oncol 5(8):1145-1168.

Wilson TJ, Nannuru KC, Futakuchi M, Singh RK. 2010. Cathepsin G-mediated enhanced TGF-beta signaling promotes angiogenesis via upregulation of VEGF and MCP-1. Cancer Lett 288(2):162-169.

Wolf JS, Chen Z, Dong G, Sunwoo JB, Bancroft CC, Capo DE, Van Waes C. 2001. IL (interleukin)-1alpha promotes nuclear factor-kappaB and AP-1-induced IL-8 expression, cell survival, and proliferation in head and neck squamous cell carcinomas. Clin Cancer Res 7(6):1812-1820.

Wu M-H, Chou Y-C, Chou W-Y, Hsu G-C, Chu C-H, Yu C-P, Sun C-A. 2009. Circulating levels of leptin, adiposity and breast cancer risk. Br J Cancer 100(4):578-582.

Wyckoff J, Wang W, Lin EY, Wang Y, Pixley F, Stanley ER, Condeelis J. 2004. A paracrine loop between tumor cells and macrophages is required for tumor cell migration in mammary tumors. Cancer Res 64(19):7022-7029.

Xie G, Yao Q, Liu Y, Du S, Liu A, Guo Z, Yuan Y. 2012. IL-6induced epithelial-mesenchymal transition promotes the generation of breast cancer stem-like cells analogous to mammosphere cultures. Int J Oncol 40(4):1171-1179.

Xie Y, Sheng W, Xiang J, Ye Z, Zhu Y, Chen X, Yang J. 2008. Recombinant human IL-24 suppresses lung carcinoma cell growth via induction of cell apoptosis and inhibition of tumor angiogenesis. Cancer Biother Radiopharm 23(3):310-320.

Xu J, Lamouille S, Derynck R. 2009. TGF-beta-induced epithelial to mesenchymal transition. Cell Res 19(2):156-172.

Yilmaz M, Christofori G. 2009. EMT, the cytoskeleton, and cancer cell invasion. Cancer Metastasis Rev 28(1-2):15-33.

Yin X, Wolford CC, Chang Y-S, McConoughey SJ, Ramsey SA, Aderem A, Hai T. 2010. ATF3, an adaptive-response gene, enhances TGF beta $\}$ signaling and cancer-initiating cell features in breast cancer cells. J Cell Sci $123(\mathrm{Pt}$ 20):3558-3565.

Yin Y, Chen X, Shu Y. 2009. Gene expression of the invasive phenotype of TNF-alpha-treated MCF-7 cells. Biomed Pharmacother 63(6):421-428.

Yoshimura A, Wakabayashi Y, Mori T. 2010. Cellular and molecular basis for the regulation of inflammation by TGFbeta. J Biochem 147(6):781-792.

Yu Y, Wang Y, Ren X, Tsuyada A, Li A, Liu LJ, Wang SE. 2010. Context-dependent bidirectional regulation of the MutS homolog 2 by transforming growth factor $\beta$ contributes to chemoresistance in breast cancer cells. Mol Cancer Res 8(12):1633-1642.

Zhang GJ, Adachi I. 1999. Serum interleukin-6 levels correlate to tumor progression and prognosis in metastatic breast carcinoma. Anticancer Res 19(2B):1427-1432.

Zhao Y, Sun R, You L, Gao C, Tian Z. 2003. Expression of leptin receptors and response to leptin stimulation of human natural killer cell lines. Biochem Biophys Res Commun 300(2):247-252.

Zheng LM, Ojcius DM, Garaud F, Roth C, Maxwell E, Li Z, King I. 1996. Interleukin-10 inhibits tumor metastasis through an NK cell-dependent mechanism. J Exp Med 184(2):579-584.

Zhou L, Ivanov II, Spolski R, Min R, Shenderov K, Egawa T, Littman DR. 2007. IL-6 programs T(H)-17 cell differentiation by promoting sequential engagement of the IL-21 and IL-23 pathways. Nat Immunol 8(9):967-974.

Zhu P, Baek SH, Bourk EM, Ohgi KA, Garcia-Bassets I, Sanjo H, Rose DW. 2006. Macrophage/cancer cell interactions mediate hormone resistance by a nuclear receptor derepression pathway. Cell 124(3):615-629.

Ziober BL, Willson JK, Hymphrey LE, Childress-Fields K, Brattain MG. 1993. Autocrine transforming growth factoralpha is associated with progression of transformed properties in human colon cancer cells. J Biol Chem 268(1): 691-698.

Zu X, Zhang Q, Cao R, Liu J, Zhong J, Wen G, Cao D. 2012. Transforming growth factor- $\beta$ signaling in tumor initiation, progression and therapy in breast cancer: an update. Cell Tissue Res 347(1):73-84.

Zuccari DAPDC, Leonel C, Castro R, Gelaleti GB, Jardim BV, Moscheta MG, Esteves JL. 2012. An immunohistochemical study of interleukin-8 (IL-8) in breast cancer. Acta Histochem 114(6):571-576.

Address correspondence to: Dr. Jorge Morales-Montor Departamento de Inmunología Instituto de Investigaciones Biomédicas Universidad Nacional Autónoma de México AP 70228 México City D.F. 04510 México

E-mail: jmontor66@biomedicas.unam.mx jmontor66@hotmail.com

Received 4 February 2014/Accepted 23 May 2014 